\title{
Newly developed anti-angiogenic therapy in non-small cell lung cancer
}

\author{
Jingjing $Q u^{1}$, Yongchang Zhang ${ }^{1}$, Xue Chen ${ }^{1}$, Haiyan Yang ${ }^{1}$, Chunhua Zhou ${ }^{1}$ and \\ Nong Yang ${ }^{1}$ \\ ${ }^{1}$ Department of Lung Cancer and Gastrointestinal Oncology Medicine, Hunan Cancer Hospital, Affiliated Cancer Hospital of \\ Xiangya School of Medicine, Changsha, 410013, China
}

Correspondence to: Nong Yang, email: yangnong0217@163.com

Keywords: angiogenesis; combined with chemotherapy; tyrosine kinase inhibitor; immunotherapy; NSCLC

Received: August 13, $2017 \quad$ Accepted: November 16, $2017 \quad$ Published: December 26, 2017

Copyright: Qu et al. This is an open-access article distributed under the terms of the Creative Commons Attribution License 3.0 (CC BY 3.0), which permits unrestricted use, distribution, and reproduction in any medium, provided the original author and source are credited.

\begin{abstract}
Angiogenesis and its role in the growth and development of non-small cell lung cancer (NSCLC) metastases has become an increasing clinical problem. Vascular endothelial growth factor (VEGF) plays a key role in advanced NSCLC. To some extent, anti-angiogenic therapies acquired some efficacy in combination with chemotherapy, target therapy and immunotherapy. However, the reliable clinical benefit obtained with these drugs is still questionable and often quantitatively limited. In this review, the authors highlight the data obtained from first-line, second-line, epidermal growth factor receptor tyrosine kinase inhibitor(EGFR-TKI) target therapy and immunotherapy in NSCLC patients who are treated with anti-angiogenic molecules in advanced NSCLC. The purpose of this study is to help us truly understand how to best use angiogenesis therapy in advanced NSCLC.
\end{abstract}

\section{INTRODUCTION}

Treatment strategies of lung cancers have expanded greatly in recent years with the development of targeting therapy in cancer-specific oncogenic driver mutations, such as the epidermal growth factor receptor (EGFR), the anaplastic lymphoma kinase (ALK) and ROS1 rearrangements. However, these molecularly targeted therapeutic strategies have been restricted to the development of secondary resistance, which has led to treatment failure.

Angiogenesis plays a major role in the development, progression and metastatic spread of solid tumors [1]. As far as we know, there are three main types of angiogenesis in physical or pathological situations. Under physiological circumstances, the development of the vasculature involves the birth of new endothelial cells and their assembly into tubes, in addition to the sprouting (angiogenesis) of new vessels from existing ones during embryogenesis. Following this morphogenesis, the normal vasculature becomes largely quiescent. Second, in the adult, as part of physiologic processes such as wound healing and female reproductive cycling, angiogenesis is turned on, but only transiently. During carcinogenesis, an "angiogenic switch" is almost always activated and remains on, causing the normally quiescent vasculature to continually sprout new vessels that help sustain expanding neoplastic tumor growths, maintain nutrients and oxygen and evacuate metabolic wastes and carbon dioxide [2]

Several molecular drivers and signaling pathways are involved in tumor angiogenesis. The pro-angiogenic factors include vascular endothelial growth factor (VEGF), platelet-derived growth factor (PDGF), fibroblast growth factor (FGF), and the angiopoietins (Figure 1) [3]. The VEGF family includes VEGFA (usually referred to as VEGF), VEGFB, VEGFC, VEGFD, and platelet-derived growth factor (PDGF). VEGF stimulates angiogenesis via VEGF receptors (VEGFRs) and ligands. When ligands are activated, VEGFRs lead to dimerization and autophosphorylation and activates the downstream signaling pathway. This leads to endothelial cell survival, proliferation, and migration. VEGF also induces vasodilation and acts as a vascular permeability factor, which underlies its significance in tissue inflammation and the tumor microenvironment.

To establish the concrete benefit of the application of an anti-angiogenic strategy in lung cancer treatment, 
several clinical trials have been conducted or are currently ongoing. The aim of this review is to collect the main antiangiogenic molecules derived from the first line, second line and target therapy trials conducted in non-small cell lung cancer (NSCLC) patients.

\section{Combination of antiangiogenic and chemotherapy in first-line of NSCLC}

\section{Bevacizumab}

Bevacizumab is a monoclonal antibody that works directly against VEGF. This preliminary result prompted a phase III trial (ECOG 4599) conducted by the Eastern Cooperative Oncology group, which resulted in FDA approval of bevacizumab in combination with carboplatin and paclitaxel for patients with non-squamous NSCLC [4].In this study, the addition of bevacizumab to paclitaxel plus carboplatin in the treatment of NSCLC has a significant survival benefit. Another phase III trial (AVAiL) was conducted to evaluate the effect of bevacizumab in combination with gemcitabine and cisplatin in first-line management of advanced NSCLC [5]. The AVAiL trial confirms the efficacy of bevacizumab when combined with this chemotherapy regimen. To evaluate the safety and efficacy of first-line bevacizumabcontained chemotherapy in a broader patient population, the SAiL study recruited 2212 patients with advanced or recurrent non-squamous NSCLC from 40 countries across six continents. The results demonstrated that bevacizumab has manageable and acceptable safety as a first-line therapeutic combined with standard chemotherapy [6]. The results of the SAiL trial are further confirmed by another phase IV trial (ARIES), which conducted the analysis of several age subgroups in 1967 advanced nonsquamous NSCLC patients. Progression-free-survival (PFSs) across each age subgroup were similar, while the overall survival (OS) in younger patients $(\leq 65$ and $\leq 75$ years) was better than older patients ( $\geq 65$ and $\geq 75$ years). This study indicated that bevacizumab in combination with chemotherapy is a viable first-line treatment option for the elderly with advanced non-squamous NSCLC [7]. A Japanese randomized phase II trial (JO19907) showed a significantly increased ORR but no improvement of median OS in patients with carboplatin-paclitaxel plus bevacizumab versus chemotherapy alone [8]. The clinically meaningful benefits of adding bevacizumab to carboplatin and paclitaxel in Chinese patients was further confirmed in a phase III BEYOND trial. Those positive results demonstrated the efficacy of bevacizumab in the Asian populations [9]. All the specific data are shown in Table 1. On the other hand, countless numbers of trials have been conducted with bevacizumab in NSCLC. The most recent data are reported in Table 1 [10-14].

\section{Ombrabulin}

Ombrabulin is a vascular disrupting agent (VDA) that stops the tumor blood flow independent of the tumor site and the specific type of cancer (Table 2) [15]. The DISRUPT trial showed that 176 patients with metastatic

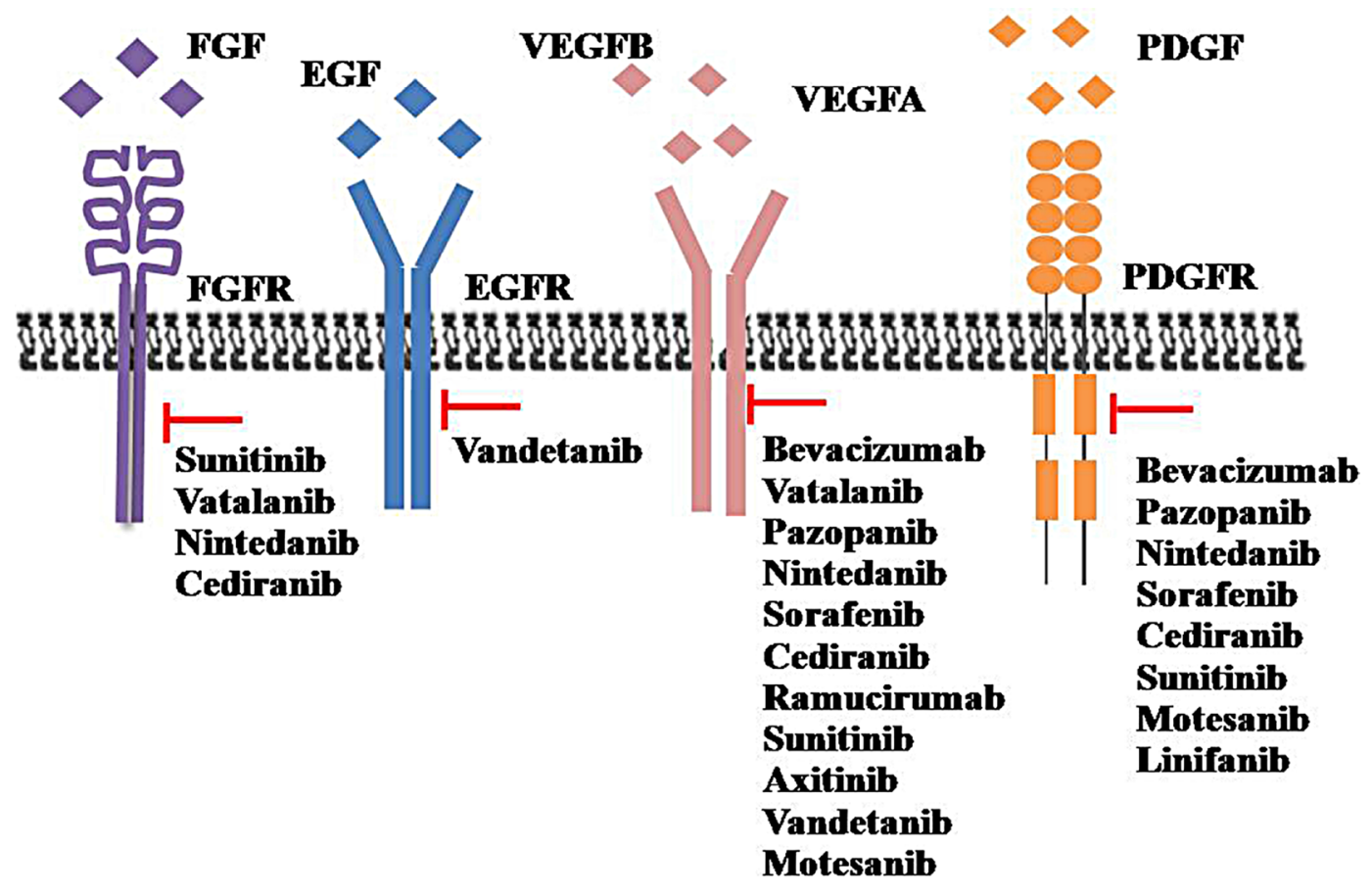

Figure 1: The main anti-angiogenic with their relevant potential targeted molecules. FGF: Fibroblast growth factor; FGFR: Fibroblast growth factor receptors; EGF: Epidermal growth factor; EGFR: Epidermal growth factor receptor; VEGF: Vascular endothelial growth factor; VEGFR: Vascular endothelial growth factor receptor; PDGF: Platelet-derived growth factor; PDGFR: Platelet-derived growth factor receptor. 
Table 1: Combination of bevacizumab and chemotherapy in first-line of NSCLC

\begin{tabular}{|c|c|c|c|c|c|c|c|c|c|}
\hline Agent & Target & Arms & No & Stage & $\begin{array}{c}\text { ORR } \\
\text { of }(\%)\end{array}$ & $\begin{array}{l}\text { PFS } \\
(\mathrm{ms})\end{array}$ & $\begin{array}{c}\text { OS } \\
(\mathrm{ms})\end{array}$ & Note & Ref \\
\hline \multirow[t]{11}{*}{ Bevacizumab } & \multirow[t]{4}{*}{ VEGF } & $\begin{array}{l}\text { Paclitaxel + carboplatin } \\
\text { Paclitaxel+carboplatin } \\
\text { +bevacizumab }\end{array}$ & $\begin{array}{l}444 \\
434\end{array}$ & \multicolumn{2}{|l|}{ IIIB or IV } & $\begin{array}{l}4.5 \\
6.2\end{array}$ & $\begin{array}{l}10.3 \\
12.3\end{array}$ & $\begin{array}{l}\text { Excellent results } \\
\text { with an excellent } \\
\text { PFS and OS }\end{array}$ & {$[4]$} \\
\hline & & $\begin{array}{l}\text { Cisplatin+ gemcitabine } \\
\text { Cisplatin+ gemcitabine } \\
+7.5 \mathrm{mg} / \mathrm{kg} \text { bevacizumab } \\
\text { Cisplatin }+ \text { gemcitabine } \\
+15 \mathrm{mg} / \mathrm{kgbevacizumab}\end{array}$ & $\begin{array}{l}345 \\
351\end{array}$ & Advanced NSCLC & $\begin{array}{l}20.1 \\
34.1 \\
30.4\end{array}$ & $\begin{array}{l}6.1 \\
6.7 \\
6.5\end{array}$ & - & $\begin{array}{l}\text { The secondary } \\
\text { end point of OS is } \\
\text { currently immature } \\
\text { because of limited } \\
\text { follow-up }\end{array}$ & {$[5]$} \\
\hline & & $\begin{array}{l}\text { Taxane-containing } \\
\text { regimen Cisplatin doublets } \\
\text { Bevacizumab were } \\
\text { carboplatin doublets }\end{array}$ & $\begin{array}{l}794 \\
829 \\
1087\end{array}$ & $\begin{array}{l}\text { Advancednon- } \\
\text { squamous NSCLC }\end{array}$ & - & $\begin{array}{l}7.8 \\
7.6\end{array}$ & $\begin{array}{l}- \\
14.3 \\
14.7\end{array}$ & $\begin{array}{l}\text { Acceptable safety as } \\
\text { a first-line combined } \\
\text { with standard } \\
\text { chemotherapy }\end{array}$ & {$[6]$} \\
\hline & & $\begin{array}{l}\text { Bevacizumab with } \\
\text { chemotherapy } \\
<65 \text { years } \\
>65 \text { years } \\
<75 \text { years } \\
>75 \text { years }\end{array}$ & $\begin{array}{l}954 \\
\\
1013 \\
1597 \\
370\end{array}$ & $\begin{array}{l}\text { Advanced non- } \\
\text { squamous NSCLC }\end{array}$ & & $\begin{array}{l}6.8 \\
6.6 \\
6.6\end{array}$ & $\begin{array}{r}14.2 \\
12.1 \\
13.5 \\
11.6\end{array}$ & $\begin{array}{l}\text { Bevacizumab in } \\
\text { combination with } \\
\text { chemotherapy is } \\
\text { a viable first-line } \\
\text { treatment option } \\
\text { for elderly with } \\
\text { advanced non- } \\
\text { squamous NSCLC. }\end{array}$ & {$[7]$} \\
\hline & & $\begin{array}{l}\text { Carboplatin-paclitaxel } \\
\text { Bevacizumab+ } \\
\text { carboplatin-paclitaxel }\end{array}$ & $\begin{array}{l}59 \\
121\end{array}$ & $\begin{array}{l}\text { IIIB/IV non- } \\
\text { squamous NSCLC }\end{array}$ & $\begin{array}{l}31.0 \\
60.7\end{array}$ & $\begin{array}{l}5.9 \\
6.9\end{array}$ & $\begin{array}{l}>22 \mathrm{~ms} \\
>22 \mathrm{~ms}\end{array}$ & $\begin{array}{l}\text { Not sufficiently } \\
\text { powered to assess } \\
\text { the OS benefit of } \\
\text { bevacizumab plus } \\
\text { CP }\end{array}$ & {$[8]$} \\
\hline & & $\begin{array}{l}\text { Carboplatin-paclitaxel } \\
\text { Bevacizumab+ carboplatin- } \\
\text { paclitaxel }\end{array}$ & $\begin{array}{l}138 \\
138\end{array}$ & $\begin{array}{l}\text { Advanced non- } \\
\text { squamous NSCLC }\end{array}$ & $\begin{array}{l}26 \\
54\end{array}$ & $\begin{array}{l}6.5 \\
9.2\end{array}$ & $\begin{array}{l}17.7 \\
28.5\end{array}$ & $\begin{array}{l}\text { Excellent results } \\
\text { with an excellent } \\
\text { PFS and OS in } \\
\text { Chinese }\end{array}$ & [9] \\
\hline & & $\begin{array}{l}\text { Bevacizumab+carboplatin- } \\
\text { pemetrexed } \\
\text { Brain metastases } \\
\text { Without brain metastases }\end{array}$ & $\begin{array}{l}11 \\
28\end{array}$ & $\begin{array}{l}\text { Advanced non- } \\
\text { squamous NSCLC }\end{array}$ & - & $\begin{array}{l}8.2 \\
8.0\end{array}$ & $\begin{array}{l}14.0 \\
12.0\end{array}$ & $\begin{array}{l}\text { The significant in } \\
\text { brain metastases was } \\
\text { unclear because of } \\
\text { the smaller sample }\end{array}$ & {$[10]$} \\
\hline & & $\begin{array}{l}\text { Paclitaxel/carboplatin } \\
\text { + axitinib Paclitaxel/ } \\
\text { carboplatin + bevacizumab }\end{array}$ & $\begin{array}{l}58 \\
60\end{array}$ & IIIB/IV & $\begin{array}{l}29.3 \\
43.3\end{array}$ & $\begin{array}{l}5.7 \\
6.1\end{array}$ & $\begin{array}{l}10.6 \\
13.3\end{array}$ & $\begin{array}{l}\text { Discontinued for } \\
\text { lack of efficacy and } \\
\text { safety issues }\end{array}$ & {$[11]$} \\
\hline & & $\begin{array}{l}\text { Carboplatin/ } \\
\text { paclitaxel + bevacizumab }\end{array}$ & 67 & $\begin{array}{l}\text { IV non-squamous } \\
\text { NSCLC with } \\
\text { asymptomatic brain } \\
\text { metastases }\end{array}$ & 62.7 & 6.7 & 16.0 & $\begin{array}{l}\text { Encouraging } \\
\text { efficacy and } \\
\text { acceptable safety } \\
\text { with NSCLC and } \\
\text { asymptomatic, } \\
\text { untreated brain } \\
\text { metastases }\end{array}$ & {$[12]$} \\
\hline & & Pemetrexed + bevacizumab & 12 & $\begin{array}{l}\text { III/IV Non- } \\
\text { squamous NSCLC } \\
\text { age } \geq 70\end{array}$ & 25 & 5.4 & 13.6 & $\begin{array}{l}\text { Well tolerated and } \\
\text { shows promise as } \\
\text { first-line treatment } \\
\text { for elderly NSCLC } \\
\text { patients }\end{array}$ & {$[13]$} \\
\hline & & $\begin{array}{l}\text { Carboplatin- paclitaxel+ } \\
\text { bevacizumab }\end{array}$ & 36 & $\begin{array}{l}\text { III/IV Non- } \\
\text { squamous NSCLC } \\
\text { age } \geq 70\end{array}$ & - & 8.4 & 29.2 & $\begin{array}{l}\text { Feasible, effective } \\
\text { first-line regimen } \\
\text { for elderly NSCLC } \\
\text { patients }\end{array}$ & {$[14]$} \\
\hline
\end{tabular}

NSCLC received ombrabulin $35 \mathrm{mg} / \mathrm{m}^{2}$ or placebo followed by a taxane-platinum regimen every 3 weeks. The results demonstrate that the median PFS was not significantly improved with ombrabulin vs placebo (5.65 vs 5.45 months; $P=0.39$ ). The two groups showed a similar OS (median
11.0 months in both groups), ORR ( $32 \%$ ombrabulin VS $31 \%$ placebo) and similar safety profiles [16].

\section{Axitinib}

Axitinib is an oral, potent, selective inhibitor of VEGFR. Single agent axitinib reduced micro-vessel 
density and induced tumor necrosis in a murine Lewis lung carcinoma model and demonstrated dose-dependent inhibition of the tumor growth [17]. Axitinib demonstrated single-agent activity in patients with advanced NSCLC [18]. Single use axitinib demonstrated an anti-tumor response in two patients with NSCLC. A phase II study evaluated the efficacy and safety of single-agent axitinib. In this study, the median PFS was 4.9 months overall. The median OS was 14.8 months in patients receiving first-line axitinib [19]. A randomized Phase II of first line axitinib or bevacizumab combined with paclitaxel/ carboplatin therapy for patients with advanced NSCLC did not improve the efficacy and was not as well tolerated. The median PFS for axitinib and bevacizumab was 5.7 and 6.1 months, respectively [HR 1.09; 95\% CI: 0.68-1.76; P $=0.64]$, while the median OS was 10.6 and 13.3 months (HR 1.12, 95\% CI 0.74-1.69; $P=0.70$ ). The ORRs were $29.3 \%$ and $43.3 \%$ [11]. Another randomized Phase II study recruited 170 patients. The patients received axitinib with or without combined pemetrexed and cisplatin that resulted in non-significant differences in PFS and OS [20]. However, further trails need to be adapted for clinical evaluation.

\section{Ramucirumab}

Ramucirumab is a monoclonal antibody that specifically targets the domain of VEFR receptor 2 . A randomized first-line Phase II trial was conducted to compare the efficiency of pemetrexed and carboplatin (or cisplatin) and ramucirumab plus pemetrexed and carboplatin (or cisplatin) once every 3 weeks. No significant difference was seen in the PFS (5.6 months for the pemetrexed-platinum and 7.2 months for the ramucirumab-pemetrexed-platinum, $P=0.132$ ) or the ORR $(8.0 \%$ and $49.3 \%$ for the pemetrexed-platinum and ramucirumab-pemetrexed-platinum arms, respectively $P$ $=0.180)$. However, there is a significant disease control rate between pemetrexed-platinum and the ramucirumabpemetrexed-platinum (70.4\% VS $85.5 \%, P=0.032)$. This study showed that ramucirumab has clinical activity in combination with pemetrexed and platinum in nonsquamous NSCLC patients [21]. The other first-line Phase II study investigating whether the addition of ramucirumab improves the PFS in advanced NSCLC. Forty patients with advanced NSCLC received ramucirumab followed by paclitaxel and carboplatin on day 1 every 21 days as a first-line therapy. The 6-month PFS rate was 59.0\%, and the ORR was $55.0 \%$. This study validates that ramucirumab in combination with paclitaxel-carboplatin results in a 6-month PFS rate and safety profile [22].

\section{Bavituximab}

Bavituximab is a chimeric monoclonal antibody directed against the membrane phospholipid phosphatidylserine (PS). Bavituximab enhanced antitumor immunity. Several preclinical investigations have demonstrated the efficacy of bavituximab in combination with other modalities against the development of multiple cancers [23]. An open-label Phase II study was conducted to assay the efficiency of bavituximab in patients with stage IIIB/IV NSCLC. The $175 \mathrm{mg} / \mathrm{m}^{2}$ of paclitaxel was administered every 21 days with weekly treatments of $3 \mathrm{mg} / \mathrm{kg}$ bavituximab followed by bavituximab monotherapy were conducted in 49 patients with up to six cycles of carboplatin until progression or unacceptable toxicity. The primary efficacy endpoint of the ORR was $40.8 \%$. The median PFS and OS were 6.0 and 12.4 months, respectively. This study showed bavituximab in combination with paclitaxel-carboplatin with a tolerable safety profile and potential efficacy in patients with advanced NSCLC [24].

\section{Linifanib}

Linifanib is a potent, orally active, and selective inhibitor of VEGR and PDGFR kinase activities with clinical efficacy in NSCLC. A phase I dose-escalation study evaluated the pharmacokinetics, safety, and efficacy of linifanib in combination with carboplatin/paclitaxel in Japanese patients with advanced NSCLC. The results showed that $12.5 \mathrm{mg}$ linifanib added to carboplatin/ paclitaxel is well tolerated in Japanese patients with advanced/metastatic NSCLC [25]. Recently, the results of another Phase II trial evaluating linifanib (7.5 mg VS 12.5 $\mathrm{mg}$ ) with carboplatin and paclitaxel as first-line therapy of advanced non-squamous NSCLC were evaluated. Median PFS times were 5.4 months with chemotherapy alone, 8.3 months in linifanib $7.5 \mathrm{mg}$ combine with chemotherapy and 7.3 months in linifanib $12.5 \mathrm{mg}$ combine with chemotherapy. Median OS times were 11.3, 11.4, and 13.0 months in the chemotherapy, $7.5 \mathrm{mg}$ linifanib, and 12.5 $\mathrm{mg}$ linifanib arms, respectively. Both linifanib doses were associated with increased toxicity, particularly related to VEGF/PDGF inhibition [26].

\section{Cediranib}

Cediranib (AZD2171) is an oral tyrosine kinase inhibitor of all three VEGFRs, PDGFR and FGFR that has shown antitumor activity, including NSCLC in phase I studies. A randomized phase II study was conducted to assay the safety and efficacy of gemcitabine and carboplatin with ( $\operatorname{arm~A)}$ or without (arm B) daily oral cediranib as a first-line therapy for advanced NSCLC. A total of 58 and 29 evaluable patients were accrued to arms $\mathrm{A}$ and $\mathrm{B}$. The study met its secondary PFS end point (PFS in arm A was $48 \%, 95 \% \mathrm{CI}: 35 \%-62 \%$ ), thus meeting the protocol-specified threshold of at least $40 \%$. The ORR was $19 \%$ and the VS was $20 \%(p=1.0)$. The median OS was 12.0 versus 9.9 months $(p=0.10)$. Hence, the trial did not meet its primary ORR end point, but met its secondary PFS end point, resulting in increased toxicity [27]. A randomized double-blind trial of carboplatin and paclitaxel with daily oral cediranib or placebo in advanced NSCLC was performed. The data showed that the median OS was 12.2 and 12.1 months for cediranib 
Table 2: Combination of the other antiangiogenic and chemotherapy in first-line of NSCLC

\begin{tabular}{|c|c|c|c|c|c|c|c|c|c|}
\hline Agent & Target & Arms & No & Stage & $\begin{array}{l}\text { ORR of } \\
(\%)\end{array}$ & mPFS & mOS & Note & Ref \\
\hline Axitinib & VEGF & Axitinib $5 \mathrm{mg}$ orally & 32 & Advanced NSCLC. & 9 & 4.9 & 14.8 & $\begin{array}{l}\text { Single-agent activity } \\
\text { and well tolerated } \\
\text { with manageable } \\
\text { toxicities NSCLC. }\end{array}$ & [19] \\
\hline \multirow{4}{*}{ Ramucirumab } & \multirow{4}{*}{ VEGF } & $\begin{array}{l}\text { Paclitaxel/carboplatin } \\
\text { + axitinib Paclitaxel/ } \\
\text { carboplatin + bevacizumab }\end{array}$ & $\begin{array}{l}58 \\
60\end{array}$ & IIIB/IV & $\begin{array}{l}29.3 \\
43.3\end{array}$ & $\begin{array}{l}5.7 \\
6.1\end{array}$ & $\begin{array}{l}10.6 \\
13.3\end{array}$ & $\begin{array}{l}\text { Discontinued for lack } \\
\text { of efficacy and safety } \\
\text { issues }\end{array}$ & {$[11]$} \\
\hline & & $\begin{array}{l}\text { Pemetrexed/cisplatin } \\
\text { Pemetrexed/cisplatin }+ \\
\text { axitinib Continuously } \\
\text { Pemetrexed/cisplatin }+ \\
\text { axitinib days } 2 \text { - } 19\end{array}$ & $\begin{array}{l}57 \\
55 \\
58\end{array}$ & $\begin{array}{l}\text { Advanced non- } \\
\text { squamous NSCLC }\end{array}$ & $\begin{array}{l}26.345 .5 \\
39.7\end{array}$ & $\begin{array}{l}7.1 \\
8.0 \\
7.9\end{array}$ & $\begin{array}{l}15.9 \\
17.0 \\
14.6\end{array}$ & $\begin{array}{l}\text { No significant } \\
\text { difference in terms of } \\
\text { both PFS and OS }\end{array}$ & {$[20]$} \\
\hline & & $\begin{array}{l}\text { Pemetrexed-platinum } \\
\text { Ramucirumab+pemetrexed- } \\
\text { platinum }\end{array}$ & $\begin{array}{l}71 \\
69\end{array}$ & $\begin{array}{l}\text { Advanced/ } \\
\text { metastatic NSCLC }\end{array}$ & $\begin{array}{l}38.0 \\
49.3\end{array}$ & $\begin{array}{l}5.6 \\
7.2\end{array}$ & $\begin{array}{l}10.4 \\
13.9\end{array}$ & $\begin{array}{l}\text { No significant } \\
\text { difference in PFS,OS } \\
\text { and ORR }\end{array}$ & {$[21]$} \\
\hline & & $\begin{array}{l}\text { Paclitaxel/carboplatin }+ \\
\text { ramucirumab }\end{array}$ & 40 & Advanced NSCLC & 55 & 7.8 & 16.8 & $\begin{array}{l}\text { The study resulted in a } \\
6 \text {-month PFS rate and } \\
\text { safety profile }\end{array}$ & {$[22]$} \\
\hline Bavituximab & PS & $\begin{array}{l}\text { paclitaxel-carboplatin }+ \\
\text { Bavituximab }\end{array}$ & 49 & IIIB/IV NSCLC & 40.8 & 6.0 & 12.4 & $\begin{array}{l}\text { demonstrated a } \\
\text { tolerable safety profile } \\
\text { and potential efficacy }\end{array}$ & [24] \\
\hline & & Carboplatin- paclitaxel & & & & & & & \\
\hline \multirow[t]{2}{*}{ Linifanib } & \multirow[t]{2}{*}{$\begin{array}{l}\text { VEGR } \\
\text { PDGFR }\end{array}$} & $\begin{array}{l}\text { linifanib } 7.5 \mathrm{mg}+ \\
\text { Carboplatin- paclitaxel } \\
\text { linifanib } 12.5 \mathrm{mg}+\end{array}$ & $\begin{array}{l}47 \\
44 \\
47\end{array}$ & \multirow[t]{2}{*}{$\begin{array}{l}\text { IIIB/IV non- } \\
\text { squamous NSCLC }\end{array}$} & $\begin{array}{l}25.543 .2 \\
31.9\end{array}$ & \multirow[t]{2}{*}{$\begin{array}{l}5.4 \\
8.3 \\
7.3\end{array}$} & $\begin{array}{l}11.3 \\
11.4 \\
13.0\end{array}$ & \multirow[t]{2}{*}{$\begin{array}{l}\text { Improved PFS with a } \\
\text { modest } \\
\text { trend for survival } \\
\text { benefit }\end{array}$} & \multirow[t]{2}{*}[26]{} \\
\hline & & Carboplatin- paclitaxel & & & & & & & \\
\hline \multirow[t]{3}{*}{ Cediranib } & \multirow[t]{3}{*}{$\begin{array}{l}\text { VEGR } \\
\text { PDGFR } \\
\text { FGFR }\end{array}$} & $\begin{array}{l}\text { Gemcitabine/carboplatin } \\
\text { Cediranib +Gemcitabine/ } \\
\text { carboplatin }\end{array}$ & $\begin{array}{l}29 \\
58\end{array}$ & IIIB/IV NSCLC & 20.019 .0 & 4.56 .3 & \multicolumn{2}{|r|}{$\begin{array}{l}\text { Did not meet its } \\
\text { primary endpoint } \\
\text { of ORR but met its } \\
\text { secondary endpoint } \\
\text { of PFS }\end{array}$} & {$[27]$} \\
\hline & & $\begin{array}{l}\text { Carboplatin- paclitaxel } \\
\text { Cediranib + Carboplatin- } \\
\text { paclitaxel }\end{array}$ & $\begin{array}{l}144 \\
143\end{array}$ & Advanced NSCLC & - & $\begin{array}{l}5.5 \\
5.5\end{array}$ & $\begin{array}{l}12.1 \\
12.2\end{array}$ & $\begin{array}{l}\text { Did not significantly } \\
\text { improve PFS or OS }\end{array}$ & {$[28]$} \\
\hline & & $\begin{array}{l}\text { Paclitaxel/carboplatin } 30 \\
\text { mg cediranib +Paclitaxel/ } \\
\text { carboplatin }\end{array}$ & $\begin{array}{l}125 \\
126\end{array}$ & Advanced NSCLC & $\begin{array}{l}16.0 \\
38.0\end{array}$ & $\begin{array}{l}5.0 \\
5.6\end{array}$ & $\begin{array}{l}10.1 \\
10.5\end{array}$ & $\begin{array}{l}30 \mathrm{mg} \text { dose not } \\
\text { tolerable for excessive } \\
\text { toxicities }\end{array}$ & [29] \\
\hline Pazopanib & $\begin{array}{l}\text { VEGFR, } \\
\text { PDGFR } \\
\text { c-Kit }\end{array}$ & $\begin{array}{l}\text { Pemetrexed- cisplatin } \\
\text { Pemetrexed+ pazopanib }\end{array}$ & $\begin{array}{l}62 \\
35\end{array}$ & $\begin{array}{l}\text { Advanced non- } \\
\text { squamous NSCLC }\end{array}$ & $\begin{array}{l}34 \\
23\end{array}$ & $\begin{array}{l}22.9 \mathrm{WS} \\
25.0 \mathrm{WS}\end{array}$ & - & $\begin{array}{l}\text { Median OS could not } \\
\text { be estimated based } \\
\text { on the collected data } \\
\text { before the study was } \\
\text { closed and survival } \\
\text { follow-up ceased }\end{array}$ & {$[31]$} \\
\hline \multirow[t]{3}{*}{ Motesanib } & \multirow[t]{3}{*}{$\begin{array}{l}\text { VEGFR, } \\
\text { PDGFR } \\
\text { c-Kit }\end{array}$} & $\begin{array}{l}\text { Carboplatin/paclitaxel } \\
\text { + motesanib } 125 \mathrm{mg} \\
\text { Carboplatin/paclitaxel } \\
\text { + motesanib } 75 \mathrm{mg} \\
\text { twice daily Carboplatin/ } \\
\text { paclitaxel + bevacizumab }\end{array}$ & 63 & $\begin{array}{l}\text { Advanced non- } \\
\text { squamous NSCLC }\end{array}$ & 37 & 8.3 & 12.8 & $\begin{array}{l}\text { The efficacy of } 125 \\
\text { mg motesanib or } \\
\text { bevacizumab was } \\
\text { comparable }\end{array}$ & [33] \\
\hline & & $\begin{array}{l}\text { Carboplatin/paclitaxel } \\
\text { Carboplatin/paclitaxel }+ \\
\text { motesanib }\end{array}$ & $\begin{array}{l}549 \\
541\end{array}$ & $\begin{array}{l}\text { IIIB/IV non- } \\
\text { squamous NSCLC }\end{array}$ & $\begin{array}{l}26 \\
43\end{array}$ & $\begin{array}{l}5.4 \\
5.6\end{array}$ & $\begin{array}{l}11.0 \\
13.0\end{array}$ & $\begin{array}{l}\text { No significantly } \\
\text { improve OS }\end{array}$ & {$[34]$} \\
\hline & & $\begin{array}{l}\text { Carboplatin/paclitaxel } \\
\text { Carboplatin/paclitaxel+ } \\
\text { motesanib } 125 \mathrm{mg}\end{array}$ & $\begin{array}{l}178 \\
182\end{array}$ & $\begin{array}{l}\text { IIIB/IV or recurrent } \\
\text { squamous NSCLC }\end{array}$ & $\begin{array}{l}35 \\
38\end{array}$ & $\begin{array}{l}5.1 \\
4.9\end{array}$ & $\begin{array}{l}10.7 \\
11.1\end{array}$ & $\begin{array}{l}\text { No significantly of } \\
\text { OS ,PFS and had } \\
\text { unacceptable toxicity }\end{array}$ & {$[35]$} \\
\hline
\end{tabular}




\begin{tabular}{|c|c|c|c|c|c|c|c|c|c|}
\hline Vandetanib & $\begin{array}{l}\text { VEGFR } \\
\text { EGFR }\end{array}$ & $\begin{array}{l}\text { Vandetanib Vandetanib+ } \\
\text { Carboplatin/paclitaxel } \\
\text { Carboplatin/paclitaxel }\end{array}$ & $\begin{array}{l}73 \\
56 \\
52\end{array}$ & Advanced NSCLC & $\begin{array}{l}7 \\
32 \\
30\end{array}$ & $\begin{array}{l}11.5 \mathrm{ws} \\
24.0 \mathrm{ws} \\
23.1 \mathrm{ws}\end{array}$ & $\begin{array}{l}10.2 \\
10.2 \\
12.6\end{array}$ & $\begin{array}{l}\text { Vandetanib } \\
\text { monotherapy had } \\
\text { shorter PFS }\end{array}$ & {$[36]$} \\
\hline & & $\begin{array}{l}\text { Gemcitabine Gemcitabine } \\
\text { + vandetanib }\end{array}$ & $\begin{array}{l}63 \\
61\end{array}$ & Advanced NSCLC & - & $\begin{array}{l}169 \mathrm{~d} \\
183 \mathrm{~d}\end{array}$ & - & $\begin{array}{l}\text { Significant } \\
\text { prolongation of PFS }\end{array}$ & {$[38]$} \\
\hline
\end{tabular}

and placebo, respectively $(p=0.72)$ and the median PFS was 5.5 months in each group $(p=0.49)$. However, the response rates (RRs) were $52 \%$ VS $34 \%$ in the cediranib and placebo arms $(p=0.001)$ with a median response duration of 4.3 (cediranib) and 4.2 months (placebo), which showed cediranib daily to carboplatin/paclitaxel chemotherapy increased RR, but not survival [28]. On the basis of a Phase II randomized trial, it was demonstrated that the addition of cediranib to carboplatin/ paclitaxel in the first-line treatment of NSCLC resulted in improved PFS (5.6 vs 5 months; $p=0.13$ ), but did not appear tolerable at a 30-mg dose. Maybe a randomized double-blind placebo-controlled trial of cediranib $20 \mathrm{mg}$ with carboplatin and paclitaxel in advanced NSCLC will be initiated [29].

\section{Pazopanib}

Pazopanib is an orally active, small molecule inhibitor targeting multiple tyrosine kinases (VEGFR, PDGFR and c-Kit). A study was designed to evaluate pazopanib as a maintenance therapy after standard firstline chemotherapy in advanced NSCLC patients. The median OS was 17.4 months for pazopanib and 12.3 months for the placebo $(p=0.257)$. The median PFS was 4.3 months versus 3.2 months $(p=0.068)$. However, this study was stopped due to a lack of efficacy by stringent PFS criteria at a futility interim analysis [30]. The randomized open-label phase II study evaluated the efficacy, safety, and tolerability of pazopanib in combination with pemetrexed compared with the cisplatin/pemetrexed in first-line patients with previously untreated, advanced, non-squamous NSCLC. However, the PFS between the pazopanib/pemetrexed and cisplatin/ pemetrexed arms were not significantly different $(25.0$ versus 22.9 weeks, respectively; $p=0.26)$ or ORR $(23 \%$ versus $34 \%$, respectively; $p=0.21$ ). Meanwhile, the OS could not be estimated based on the data collected before the study was closed and survival follow-up ceased. Unfortunately, there were three unacceptable levels of toxicity in the pazopanib/pemetrexed arm, including the ileus, tumor embolism, and bronchopneumonia/sepsis due to the final study termination [31].

\section{Motesanib}

Motesanib is a small-molecule antagonist of VEGFR, PDGFR and c-Kit. The safe maximum tolerated dose (MTD), and pharmacokinetics of motesanib were explored in advanced NSCLC in a phase IB study. It showed that motesanib was tolerable when combined with carboplatin/paclitaxel with little effect on motesanib pharmacokinetics at the $125 \mathrm{mg}$ once daily dose level. However, it needed further investigation [32]. A phase II study estimated the efficacy of paclitaxel-carboplatin (PC) plus motesanib in advanced non-squamous NSCLC. The ORR was $30 \%, 23 \%$, and $37 \%$ in the carboplatin/ paclitaxel and motesanib $125 \mathrm{mg}$ (arms A) VS carboplatin/ paclitaxel + motesanib $75 \mathrm{mg}$ twice daily (arms B) and PC + bevacizumab (arms C). The median PFS in arm A was 7.7 months; for arm B, it was 5.8 months; and for arm C, it was 8.3 months. The median OS for arm A was 14.0 months; for arm B, it was 12.8 months; and for arm C, it was 14.0 months. Taken together, this study demonstrated that $125 \mathrm{mg}$ motesanib or bevacizumab plus PC were recommended, but they had higher toxicity [33]. Another international, randomized placebo-controlled doubleblind phase III study was conducted to analyze whether motesanib plus $\mathrm{CP}$ will improve the $\mathrm{OS}$ in advanced non-squamous NSCLC. The median PFS was 5.6 months VS and 5.4 months in the carboplatin/paclitaxel plus motesanib group compared with carboplatin/paclitaxel alone $(P<0.001)$. The ORR was $43 \%$ versus $26 \%(P<0$ $.001)$. It is disappointing that the there was no significant difference in the median OS between the two groups (13.0 VS 113.0, $P=0.14$ ) and in the adenocarcinoma subset [34]. The phase 3 MONET1 study evaluated motesanib plus carboplatin/paclitaxel (Arm A) versus placebo plus carboplatin/ paclitaxel (Arm B)as a first-line therapy for stage IIIB/IV or recurrent squamous NSCLC. The median OS time was 11.1 months compared with 10.7 months (Arm A VS Arm B, $p=0.3306$ ). The median PFS times were 4.9 months and 5.1 months (Arm A VS Arm B, $p=$ 0.2294). The ORR in Arm A was 38\% compared with $35 \%$ in Arm B ( $p=0.7362)$. Most importantly, the motesanib plus PC group showed more serious adverse events, especially bleeding events [35].

\section{Vandetanib}

Vandetanib is a once daily oral inhibitor of VEGFR and epidermal growth factor receptor(EGFR) signaling. A randomized Phase II Study of vandetanib alone or with paclitaxel-carboplatin (PC) as a first line therapy in advanced NSCLC showed that vandetanib plus PC decreased the risk of progression with longer PFS [36]. A Phase I study investigated the safety, pharmacokinetics and tolerability of vandetanib with either gemcitabine plus cisplatin (GC) or vinorelbine plus cisplatin (VC) 
in patients with previously untreated locally advanced NSCLC. The results showed that vandetanib $100 \mathrm{mg} / \mathrm{d}$ in combination with either VC or GC was not tolerated and not a feasible first-line treatment for NSCLC [37]. A phase II randomized study was conducted to evaluate the efficacy and tolerability of vandetanib plus gemcitabine $(\mathrm{V} / \mathrm{G})$ compared with gemcitabine alone in advanced NSCLC. The explorative analysis showed that the median PFS was significantly prolonged in the $\mathrm{P} / \mathrm{G}$ arm compared with the V/G arm (169 days VS 183 days, $P=0.047)$. The addition of vandetanib to gemcitabine was well tolerated [38].

\section{Nintedanib}

Nintedanib is a tyrosine kinase inhibitor of VEGFR, FGFR, and PDGFR, which was involved in angiogenesis. The phase I, open-label dose-escalation study investigated BIBF 1120 (Nintedanib) combined with PC in first-line patients with advanced IIIB/IVNSCLC. The data showed that $200 \mathrm{mg}$ BIBF1120 combine with PC demonstrated an acceptable safety profile [39]. A phase II double-blind study to investigate the efficacy and safety of nintedanib, which failed first or second line platinum-based chemotherapy in advanced NSCLC. Although the median PFS (6.9 weeks) and OS (21.9 weeks) had no significant difference in nintedanib treatment, it was well tolerated and warrants further exploration [40].

\section{Combination of anti-angiogenic and chemotherapy in second-line of NSCLC (Table 3)}

\section{Bevacizumab}

It is well known that several clinical trials have authenticated bevacizumab with PC or GC and showed fantastic efficiency in the first-line therapy of advanced NSCLC. However, there is no study comparing the difference between first or second line therapy in patients with advanced NSCLC in China. The ORR were $23.1 \%$ and $5.0 \%$ in first and second line therapy $(P=0.020)$, respectively. The median OS were 27.2 months $(95 \%$ CI 13.3-41.1 months) and 29.6 months (95\% CI 6.752.5 months $)$, respectively $(P=0.740)$. At last, the study concluded that the combination of bevacizumab and chemotherapy had encouraging anti-tumor efficacy as both first and second line therapy [41]. A phase II study to analyze the efficacy of bevacizumab plus PC in advanced NSCLC with EGFR mutated as first-line therapy. The ORR was 37\% (90\% CI; 24-52\%), PFS was 6.6 months (95\% CI; 4.8-12.0 months), and the median OS was 18.2 months $(95 \% \mathrm{CI} ; 12.0-23.4$ months $)$. It is a pity that this research did not achieve the initial treatment goal [42].

\section{Nintedanib}

Several studies had tested the efficacy of nintedanib in the first-line of advanced NSCLC. The efficacy and safety of nintedanib in the setcond-line for NSCLC is still unclear. It is surprising that a large-scale clinical research LUME-Lung1 validated nintedanib in combination with docetaxel as an effective second-line option for patients with advanced NSCLC. A total of 655 patients were randomly assigned to receive docetaxel plus nintedanib and 659 patients received docetaxel plus placebo. The PFS was 2.7 months and 3.4 months in the docetaxel plus the placebo group and the docetaxel plus nintedanib group, respectively, indicating the patients benefit from the nintedanib group $(p=0.0019)$. The median OS had no significant change between the two groups; however, the OS was significantly improved for patients with adenocarcinoma histology in the docetaxel plus nintedanib group compared with the docetaxel plus placebo group (median 10.9 months vs 7.9 months, $p=0.0073$ ). The LUME-Lung1 study demonstrated that nintedanib plus docetaxel is an effective second-line option for patients with advanced NSCLC who are resistant to the first-line treatment, especially for patients with adenocarcinoma [43].

\section{Sunitinib}

Sunitinib is a small-molecule inhibitor of multiple receptor tyrosine kinases, including VEGFR, PDGFR, FGFR1 and c-KIT. The CALGB 30704 study was conducted to validate whether sunitinib therapy improved outcomes in the second-line setting of advance NSCLC compared to chemotherapy. We divided 130 eligible patients into pemetrexed alone, sunitinib alone and pemetrexed plus sunitinib groups. The median PFS was 4.9 months $(95 \% \mathrm{CI}, 2.1-8.8), 3.3$ months $(95 \%$ CI, 2.3-4.2), and 3.7 months (95\% CI, 2.5-5.8) for pemetrexed alone, sunitinib alone and the pemetrexed plus sunitinib group, respectively $(p=0.18)$. The median OS was 10.5 months (95\% CI, 8.3-20.2) for pemetrexed alone, 8.0 months $(95 \% \mathrm{CI}, 6.8-13.5)$ for sunitinib alone, and 6.7 months $(95 \% \mathrm{CI}, 4.1-10.1)$ for pemetrexed plus sunitinib $(p=0.03)$. In the subgroup analysis, there was no benefit in the PFS or OS of the pemetrexed plus sunitinib or sunitinib groups in either the squamous or non-squamous subsets. In conclusion, this study showed that the OS was significantly better with pemetrexed alone compared with the other group [44].

\section{Vatalanib}

Vatalanib (PTK787/ZK 222584, PTK/ZK) is an oral small molecular multi-tyrosine kinase inhibitor which prevents activation of VEGFR, PDGFR, and stemcell factor receptor c-kit [45]. Patients with stage IIIB/ IV NSCLC received a fixed dose of $1250 \mathrm{mg}$ vatalanib either once-daily (QD) or twice daily (TDD: $500 \mathrm{mg}$ a.m. + $750 \mathrm{mg}$ p.m.) as second line treatment until disease progression or unacceptable toxicity. The PFS was 2.1 months for QD (95\% CI, 1.0-2.9) and 2.8 for TDD (95\% CI, 2.2-4.0). The OS was 7.3 months for QD (95\% CI, 4.3-13.5) and 9.0 for TDD (95\% CI,7.4-11.6) with a 
Table 3: Combination of antiangiogenic and chemotherapy in second-line of NSCLC

\begin{tabular}{|c|c|c|c|c|c|c|c|c|c|}
\hline Agent & Target & Arms & No & Stage & $\begin{array}{l}\text { ORR } \\
\text { of }(\%)\end{array}$ & mPFS & $\mathrm{mOS}$ & Note & Ref \\
\hline \multirow[t]{2}{*}{ Bevacizumab } & VEGF & $\begin{array}{l}\text { Bevacizumab+ different } \\
\text { chemotherapy }\end{array}$ & 40 & $\begin{array}{l}\text { Advanced non- } \\
\text { squamous NSCLC }\end{array}$ & 5.0 & - & 29.6 & $\begin{array}{l}\text { Had encouraging } \\
\text { anti-tumor efficacy } \\
\text { as second line } \\
\text { therapy }\end{array}$ & {$[41]$} \\
\hline & & $\begin{array}{l}\text { Bevacizumab + Carboplatin/ } \\
\text { paclitaxel } \\
\text { after EGFR mutations }\end{array}$ & 31 & $\begin{array}{l}\text { IIIB/IV non- } \\
\text { squamous NSCLC }\end{array}$ & 37 & 6.6 & 18.2 & $\begin{array}{l}\text { Did not achieve the } \\
\text { initial treatment goal }\end{array}$ & {$[42]$} \\
\hline Nintedanib & $\begin{array}{l}\text { VEGR } \\
\text { PDGFR } \\
\text { FGFR }\end{array}$ & $\begin{array}{l}\text { Docetaxel }+ \text { placebo } \\
\text { Docetaxel }+ \text { nintedanib }\end{array}$ & $\begin{array}{l}659 \\
655\end{array}$ & IIIB/IV NSCLC & - & $\begin{array}{l}2.7 \\
3.4\end{array}$ & $\begin{array}{l}9.1 \\
10.1\end{array}$ & $\begin{array}{l}\text { Effective second- } \\
\text { line combination } \\
\text { with docetaxel }\end{array}$ & {$[43]$} \\
\hline Sunitinib & $\begin{array}{l}\text { VEGFR, } \\
\text { PDGFR, } \\
\text { FGFR } \\
\text { cKIT }\end{array}$ & $\begin{array}{l}\text { Pemetrexed } \\
\text { Sunitinib Pemetrexed }+ \text { Sunitin }\end{array}$ & $\begin{array}{l}42 \\
47 \\
41\end{array}$ & IIIB/IV NSCLC & - & $\begin{array}{l}4.9 \\
3.3 \\
3.7\end{array}$ & $\begin{array}{l}10.5 \\
8.0 \\
6.7\end{array}$ & $\begin{array}{l}\text { OS was significantly } \\
\text { better with } \\
\text { pemetrexed alone } \\
\text { compared with } \\
\text { the two sunitinib- } \\
\text { containing arms }\end{array}$ & {$[44]$} \\
\hline Vatalanib & $\begin{array}{l}\text { VEGR } \\
\text { PDGFR } \\
\text { FGFR }\end{array}$ & $\begin{array}{l}1250 \mathrm{mg} \text { vatalanib once-daily } \\
\text { Vatalanib } 500+750 \mathrm{mg}(2 \\
\text { divided dosing })\end{array}$ & $\begin{array}{l}56 \\
62\end{array}$ & IIIB/IV NSCLC & & $\begin{array}{l}2.1 \\
2.8\end{array}$ & 7.39 .0 & $\begin{array}{l}\text { Potential benefits in } \\
\text { tumor size reduction } \\
\text { and survival. }\end{array}$ & {$[46]$} \\
\hline \multirow[t]{2}{*}{ Ramucirumab } & VEGF & $\begin{array}{l}\text { Placebo-docetaxel } \\
\text { Ramucirumab+docetaxel }\end{array}$ & $\begin{array}{l}81 \\
76\end{array}$ & NSCLC & $\begin{array}{l}18.5 \\
28.9\end{array}$ & $\begin{array}{l}4.21 \\
5.22\end{array}$ & $\begin{array}{l}14.65 \\
15.15\end{array}$ & $\begin{array}{l}\text { Improved PFS with } \\
\text { a manageable safety } \\
\text { profile }\end{array}$ & {$[47]$} \\
\hline & & $\begin{array}{l}\text { Placebo-docetaxel } \\
\text { Ramucirumab+docetaxel }\end{array}$ & $\begin{array}{l}625 \\
628\end{array}$ & IV NSCLC & - & $\begin{array}{l}3.0 \\
4.5\end{array}$ & $\begin{array}{l}9.1 \\
10.5\end{array}$ & $\begin{array}{l}\text { Improves survival } \\
\text { as second-line } \\
\text { treatment }\end{array}$ & {$[48]$} \\
\hline Bavituximab & PS & $\begin{array}{l}\text { Docetaxel + bavituximab } 3 \mathrm{mg} / \\
\mathrm{kg} \text { Docetaxel + bavituximab } \\
1 \mathrm{mg} / \mathrm{kg}\end{array}$ & $\begin{array}{l}41 \\
80\end{array}$ & $\begin{array}{l}\text { Advanced or } \\
\text { metastatic NSCLC }\end{array}$ & $\begin{array}{l}17.1 \\
13.8\end{array}$ & $\begin{array}{l}4.5 \\
3.3\end{array}$ & $\begin{array}{l}11.7 \\
7.3\end{array}$ & $\begin{array}{l}\text { High dose acquired } \\
\text { longer PFS and os }\end{array}$ & {$[49]$} \\
\hline
\end{tabular}

moderate toxicity profile. In a word, it seems that TDD acquired longer a PFS and OS compared to the QD of vatalanib. Nevertheless, these results need to be validated in further randomized trials [46].

\section{Ramucirumab}

Ramucirumab is a monoclonal antibody that specifically targets the domain of VEFR receptor 2 . It is well known that ramucirumab improves the OS compared with an active comparator for previously treated NSCLC as the first new therapy [21]. On the other hand, a double-blind randomized placebo-controlled phase II study assessed the efficacy and safety of second-line ramucirumab-docetaxel in Japanese patients with NSCLC with disease progression after platinum-based therapy. The median PFS was longer with ramucirumab-docetaxel (5.22 months) than with placebo-docetaxel (4.21 months). The median OS was 15.15 months for placebo-docetaxel and 14.65 months for ramucirumab-docetaxel. The ORR was also longer in the ramucirumab-docetaxel arms. In conclusion, the Japanese patients with NSCLC acquired longer OS and PFS in the second-line of ramucirumab-docetaxel therapy [47]. A phase III trial named REVEL assessed the efficacy and safety of docetaxel plus ramucirumab or placebo as a secondline treatment for patients with stage IV NSCLC after platinum-based therapy resistance. The median OS was 10.5 months for 628 patients who received ramucirumab plus docetaxel and 9.1 months for 625 patients who received placebo plus docetaxel (HR 0.86, 95\% CI 0.75-0.98; $p=$ 0.023). The median PFS was 4.5 months for the patients in the ramucirumab group compared with 3.0 months for the control group $(p<0.0001)$. This large clinical study significantly proved that ramucirumab plus docetaxel improves survival as a second-line treatment of patients with stage IV NSCLC [48].

\section{Bavituximab}

In 2014, bavituximab was approved by the US Food and Drug Administration (FDA) as a potential treatment of second-line NSCLC. A randomized placebo-controlled phase II trial of docetaxel and bavituximab (1 and $3 \mathrm{mg} /$ $\mathrm{kg}$ ) as a second-line treatment of NSCLC was conducted. Forty-one patients were treated with bavituximab at $3 \mathrm{mg} /$ $\mathrm{kg}$ plus docetaxel, and the other 80 patients were treated with bavituximab at $1 \mathrm{mg} / \mathrm{kg}$ plus docetaxel. The ORR was $17.1 \%$ and $13.8 \%$ in the bavituximab at high dose plus 
docetaxel and the lower dose plus docetaxel, respectively. Regarding the secondary endpoints, the median PFS was 4.5 months and 3.3 months for $3 \mathrm{mg} / \mathrm{kg}$ bavituximab plus docetaxel and $1 \mathrm{mg} / \mathrm{kg}$ bavituximab plus docetaxel. The median OS was 11.7 months and 7.3 months for $3 \mathrm{mg} / \mathrm{kg}$ bavituximab plus docetaxel and $1 \mathrm{mg} / \mathrm{kg}$ bavituximab plus docetaxel, respectively. The safety of $3 \mathrm{mg} / \mathrm{kg}$ bavituximab plus docetaxel was similar to that of the control arm indicating the planned dose for the Phase III trial [49].

\section{Combination of antiangiogenic therapy and targeted therapy in NSCLC (Table 4)}

\section{Bevacizumab}

EGFR TKI, such as erlotinib and gefitinib, was the standard treatment for patients affected by NSCLC who harbored EGFR mutations. However, most patients are usually resistant to EGFR TKI treatment. Most of the trails had been under investigation to overcome the underlying mechanism of resistance to EGFR TKI, such as the MET amplification and EGFR T790M mutation [50]. The TASK study evaluated the efficacy and safety of the EGFR TKI erlotinib in combination with the bevacizumab as a first-line therapy in advanced non-squamous NSCLC patients. One hundred twenty-four patients were divided into two arms: bevacizumab plus chemotherapy (BC arm) or bevacizumab plus erlotinib (BE arm). The median PFS was 18.4 weeks versus 25.0 weeks for BE versus $\mathrm{BC}$, respectively $(p=0.0183)$. The median OS was 16.4 months for BE and was not reached for BC $(p=0.4063)$. The ORR was also without significance between the two arms (23.8\% with BE compared with $34.4 \%$ with BC, $P=0.19$ ). In conclusion, this study did not show a PFS benefit for the BE combination in first-line advanced NSCLC compared with BC [51]. The INNOVATIONS study was designed to assess the efficacy of bevacizumab plus erlotinib in first-line patients with IIIB/IV NSCLC. The response rate was $12 \%$ VS $36 \%$ in bevacizumab plus erlotinib(BE arm) compared to the cisplatin, gemcitabine and bevacizumab(CGB) arm $(p<0.0001)$. Meanwhile, the ORR and OS were also longer in the CGB arm compared to the BE arm. This study indicated that the platinumbased combination chemotherapy remains the standard of care in first-line treatment of non-non-squamous NSCLC [52]. Another phase II study was conducted to assay whether bevacizumab enhances the effect of gefitinib in the EGFR mutant NSCLCs. Forty-two patients were enrolled in the study. The 1-year median PFS time were 14.4 months (95\% CI 10.1-19.2). The median PFS differed significantly between the EGFR exon 19 deletion and the L858R point mutation (18.0 versus 9.4 months, respectively; $p=0.006)$. This study demonstrates gefitinib in combination with bevacizumab as the first-line therapy seems to be a favorable in EGFR mutated NSCLC [53]. An international multi-center single-arm phase 2 trial named BELIEF conducted done at 29 centers in eight European countries to evaluate the efficacy of erlotinib combined with bevacizumab in patients with EGFR-mutant NSCLC. The overall median PFS was 13.2 months (95\% CI 10.315.5). In the T790M-positive group, the median PFS was 16.0 months (12.7 to not estimable) whereas in the T790M-negative group, the median PFS was 10.5 months. The BELIEF study provides strong evidence of the benefit for erlotinib combined with bevacizumab in patients with NSCLC who have EGFR mutations [54].

\section{Sunitinib}

A randomized double-blind multicenter phase II trial was designed to assess the efficacy and safety of sunitinib compared to erlotinib in patients with chemotherapy pretreated NSCLC. The median duration of the follow-up was 17.7 months. The median PFS was 2.0 versus 2.8 months for erlotinib alone versus sunitinib in combination with erlotinib (HR 0.898, $P=0.321$ ). The OS was 7.6 versus 8.2 months (HR $1.066, P=0.617$ ), and the ORRs were $3.0 \%$ and $4.6 \%$, respectively. However, it is disappointing to us that sunitinib combined to erlotinib did not significantly improve the PFS in patients with advanced NSCLC [55]. A trial was undertaken to evaluate the efficacy and potential toxicity of sunitinib therapy in advanced NSCLC patients pretreated with EGFR-TKIs in China. The PFS was 1.25 months (95\% CI: 0.90-1.9 months), and the OS was 3.40 months (95\% CI: 3.00-6.80 months). There is no sign of overall clinical benefits of sunitinib detected in patients with pretreated EGFRTKIs in China. Whether sunitinib is beneficial or not for NSCLC patients pretreated with EGFR-TKIs requires further investigation [56].

\section{Sorafenib}

Sorafenib is an oral multi-kinase inhibitor targeting the receptor tyrosine, including receptors for VEGF and FDGFR and c-Kit. A multinational double-blind placebo-controlled monotherapy phase III trial named MISSION administered sorafenib as third-/fourth-line treatment with advanced NSCLC. The median OS was 8.2 months in the sorafenib $(n=350)$ and 8.3 months in the placebo groups $(n=353$, $p=0.47)$. The median PFS was 2.8 versus 1.4 months $(p<$ 0.0001). However, among 89 patients with EGFR mutations, the OS (13.9 versus 6.5 months; $p=0.002)$ and PFS (2.7 versus 1.4 months; $p<0.001)$ were significantly higher with sorafenib than the placebo. This study showed that, as third-/ fourth-line treatment with advanced NSCLC, sorafenib did not significantly increase the OS, but did increase the PFS [57]. The CTONG 0805 study was designed to assay the efficacy and safety of sorafenib in patients with advanced lung adenocarcinoma after failure of EGFR-TKIs therapy in China. The median PFS and OS were 3.7 months [95\% CI, 3.5-3.9 months] and 7.4 months (95\% CI, 5.7-9.2 months), respectively. It showed that sorafenib monotherapy did not achieve positive results in patients in the CTONG 0805 trial [58]. A randomized double-blind placebo-controlled Phase II 
Table 4: Combination of antiangiogenic therapy and targeted therapy in NSCLC

\begin{tabular}{|c|c|c|c|c|c|c|c|c|c|}
\hline Agent & Target & Arms & No & Stage & $\begin{array}{l}\text { ORR } \\
\text { of }(\%)\end{array}$ & mPFS & mOS & Note & Ref \\
\hline \multirow[t]{4}{*}{ Bevacizumab } & \multirow[t]{4}{*}{ VEGF } & $\begin{array}{l}\text { Erlotinib+bevacizumab } \\
\text { Chemotherapy+ bevacizumab }\end{array}$ & $\begin{array}{l}63 \\
61\end{array}$ & $\begin{array}{l}\text { Advanced } \\
\text { non-squamous } \\
\text { NSCLC }\end{array}$ & $\begin{array}{l}23.8 \\
34.4\end{array}$ & $\begin{array}{l}18.4 \mathrm{ws} \\
25.0 \mathrm{ws}\end{array}$ & $\begin{array}{l}16.4 \\
-\end{array}$ & $\begin{array}{l}\text { Did not show a benefit } \\
\text { in terms of PFS for } \\
\text { BE. OS was not } \\
\text { reached in BC arms. }\end{array}$ & {$[51]$} \\
\hline & & $\begin{array}{l}\text { Erlotinib+bevacizumab } \\
\text { Cisplatin- } \\
\text { gemcitabine+bevacizumab }\end{array}$ & $\begin{array}{l}111 \\
113\end{array}$ & $\begin{array}{l}\text { Advanced } \\
\text { non-squamous } \\
\text { NSCLC }\end{array}$ & $\begin{array}{l}12 \\
36\end{array}$ & $\begin{array}{l}3.5 \\
6.9\end{array}$ & $\begin{array}{l}12.6 \\
17.8\end{array}$ & $\begin{array}{l}\text { The ORR,PFS and OS } \\
\text { were shorter in BE arm }\end{array}$ & {$[52]$} \\
\hline & & Gefitinib + bevacizumab & 42 & $\begin{array}{l}\text { Advanced } \\
\text { non-squamous } \\
\text { NSCLC }\end{array}$ & 73.8 & 14.4 & - & $\begin{array}{l}\text { OS had not yet been } \\
\text { reached because of } \\
\text { severe adverse events }\end{array}$ & {$[53]$} \\
\hline & & Erlotinib + bevacizumab & 109 & $\begin{array}{l}\text { IIIB/IV lung } \\
\text { adenocarcinoma }\end{array}$ & - & 13.2 & - & $\begin{array}{l}\text { Acquired benefit } \\
\text { for the combined } \\
\text { use of erlotinib and } \\
\text { bevacizumab }\end{array}$ & {$[54]$} \\
\hline \multirow[t]{2}{*}{ Sunitinib } & \multirow[t]{2}{*}{$\begin{array}{l}\text { VEGFR, } \\
\text { PDGFR, } \\
\text { FGFR } \\
\text { cKIT }\end{array}$} & Erlotinib Erlotinib + sunitinib & $\begin{array}{l}64 \\
64\end{array}$ & IIIB/IV NSCLC & $\begin{array}{l}3.0 \\
4.6\end{array}$ & $\begin{array}{l}2.0 \\
2.8\end{array}$ & $\begin{array}{l}7.6 \\
8.2\end{array}$ & $\begin{array}{l}\text { The combination did } \\
\text { not improve PFS }\end{array}$ & {$[55]$} \\
\hline & & $\begin{array}{l}\text { Sunitinib+ pretreated EGFR- } \\
\text { TKIs }\end{array}$ & 30 & $\begin{array}{l}\text { pretreated EGFR- } \\
\text { TKIs NSCLC }\end{array}$ & - & 1.25 & 3.40 & $\begin{array}{l}\text { No sign of overall } \\
\text { clinical benefits }\end{array}$ & {$[56]$} \\
\hline \multirow[t]{3}{*}{ Sorafenib } & \multirow[t]{3}{*}{$\begin{array}{l}\text { VEGFR } \\
\text { PDGFR } \\
\text { c-Kit }\end{array}$} & $\begin{array}{l}\text { Sorafenib+ erlotinib } \\
\text { Placebo+ erlotinib }\end{array}$ & $\begin{array}{l}111 \\
55\end{array}$ & $\begin{array}{l}\text { IIIB or IV } \\
\text { NSCLC }\end{array}$ & $\begin{array}{l}8 \\
11\end{array}$ & $\begin{array}{l}3.38 \\
1.94\end{array}$ & $\begin{array}{l}7.62 \\
7.23\end{array}$ & $\begin{array}{l}\text { Did not statistically } \\
\text { improve ORR or } \\
\text { PFS combined with } \\
\text { erlotinib }\end{array}$ & {$[59]$} \\
\hline & & $\begin{array}{l}\text { Gemcitabine }+ \text { sorafenib } \\
\text { Erlotinib }+ \\
\text { sorafenib }\end{array}$ & $\begin{array}{l}31 \\
29\end{array}$ & $\begin{array}{l}\text { Advanced } \\
\text { NSCLC }\end{array}$ & $\begin{array}{l}6.5 \\
10.3\end{array}$ & - & $\begin{array}{l}6.55 \\
12.6\end{array}$ & $\begin{array}{l}\text { Erlotinib plus } \\
\text { sorafenib was feasible } \\
\text { in elderly patients }\end{array}$ & {$[60]$} \\
\hline & & Sorafenib + erlotinib & 46 & $\begin{array}{l}\text { Advanced } \\
\text { NSCLC }\end{array}$ & 30.4 & - & - & $\begin{array}{l}\text { Well-tolerated and } \\
\text { effective against } \\
\text { advanced NSCLC }\end{array}$ & {$[61]$} \\
\hline
\end{tabular}

trial was designed to evaluate the efficacy of sorafenib plus erlotinib in advanced NSCLC. The median PFS was 3.38 months in the sorafenib-erlotinib group and 1.94 months in the erlotinib-placebo group $(P=0.196)$. The median OS was 7.62 months in the sorafenib-erlotinib group and 7.23 months in the placebo-erlotinib group $(P=0.290)$. In 67 patients with EGFR wild-type tumors, the median PFS was 3.38 months for sorafenib-erlotinib VS 1.77 months for the placebo- erlotinib group $(P=0.018)$. The median OS was 8 months for sorafenib-erlotinib VS 4.5 months for the placebo-erlotinib group $(P=0.019)$. The subset analyses in the EGFR WT showed a benefit for the combination of erlotinib-sorafenib; however, failed in all of the advanced NSCLC patients [59]. The aim of a multicenter, randomized phase II study was to evaluate the clinical activity and safety of sorafenib in combination with erlotinib or gemcitabine in unselected untreated elderly patients with NSCLC. The ORR was $6.5 \%$ for the gemcitabine plus sorafenib group and $10.3 \%$ for the combination of erlotinib plus sorafenib.
The median OS was 6.55 months for the gemcitabine plus sorafenib patients and 12.6 months for the erlotinib plus sorafenib patients. The erlotinib-sorafenib combination was feasible in elderly patients with advanced NSCLC [60]. Recently, the KCSG-0806 study determined the clinical activity of sorafenib in combination with erlotinib in patients with advanced NSCLC. The overall response rate was $30.4 \%$. In the EGFR mutation, the ORRs were $62.5 \%, 6.7 \%$ and $34.8 \%(P=0.013)$ in the EGFR wild type and EGFR unknown tumor subgroup. It appears that sorafenib plus erlotinib is effective against advanced NSCLC [61].

\section{Anti-angiogenic combined with immunotherapy}

\section{The mechanism of anti-angiogenic regulated the tumor microenvironment}

It is well known that the tumor microenvironment plays a key role in tumor progression. It is also obvious 
that anti-angiogenics can stimulate the immune system through altering the tumor microenvironment. Several studies showed that VEGF was an important factor in the immunosuppressive micro-environment that enable the tumor to evade immune-surveillance and induce angiogenesis through some mechanisms. It is reported that VEGF can promote and the induction of inhibitory immune-cell growth, including T-regulatory cells and myeloid derived suppressor cells (MDSCs), as well as inhibition of T-cell development (Figure 2). On the other hand, VEGF influences lymphocyte trafficking across the endothelia to the tumor by inhibiting lymphocyte adhesion. Because of defects in endothelial intercellular adhesion molecule-1 (ICAM-1) and vascular cell adhesion molecule-1 (VCAM-1), there is clustering at the endothelial cell surface, thereby blocking T-cell infiltration into tumors [62]. It is well known that anti-angiogenic agents can reduce tumor compactness and vasculature, resulting in improved oxygenation of the tumor microenvironment. In recent years, immunotherapies targeting the T-cell immune checkpoint receptor PD-1, or its ligand PD-L1 and cytotoxic T lymphocyte-associated protein 4 (CTLA-4), have led to significant improvements in some cancer prognosis.

\section{Anti-angiogenic combined with PD-1 or CTLA-4 inhibitors in NSCLC}

The recent success of programmed cell death- 1 (PD-1) and programmed cell death ligands (PD-L1 and PDL-2) in the treatment of cancer has emphasized the essential role of the eradication of tumors by preventing T-cell-mediated destruction. The PD-1 pathway is a T-cell inhibitory pathway that is induced by the binding of the PD-1 receptor on the T-cell plasma membrane to PD-L1 on the tumor. Tumor cells have blocked this pathway by up-regulating PD-L1 expression [63]. In the rapidly evolving area, PD-1 inhibitors nivolumab, pembrolizumab and atezolizumab are approved for the treatment of NSCLC. It is reported that sunitinib decreased PD-1 expression and increased the infiltration of CD-4+ T cells into the tumor [64]. Multiple trials are currently investigating combinations of antiangiogenic agents and immunotherapies in NSCLC. The NCT01454102 trial studies the efficiency of bevacizumab plus nivolumab in the III/IV NSCLC. The median PFS was 37.1 weeks in the bevacizumab plus nivolumab arm and 21.4 weeks in the non-squamous patients in the nivolumab monotherapy arm. The ORR was almost the same between the two arms. However, the median OS was not reached in either arm. In addition, the bevacizumab plus nivolumab arm showed less toxicity. In conclusion, bevacizumab plus nivolumab improved the PFS for maintenance therapy in advanced NSCLC with a tolerable safety profile [65]. However, the clinical trials of combined treatment with the PD-L1 inhibitor ramucirumab plus pembrolizumab and bevacizumab plus atezolizumab in advanced non-squamous NSCLC are currently ongoing. For the treatment of anti-angiogenic agents combined with the CTLA-4 inhibitor in advanced

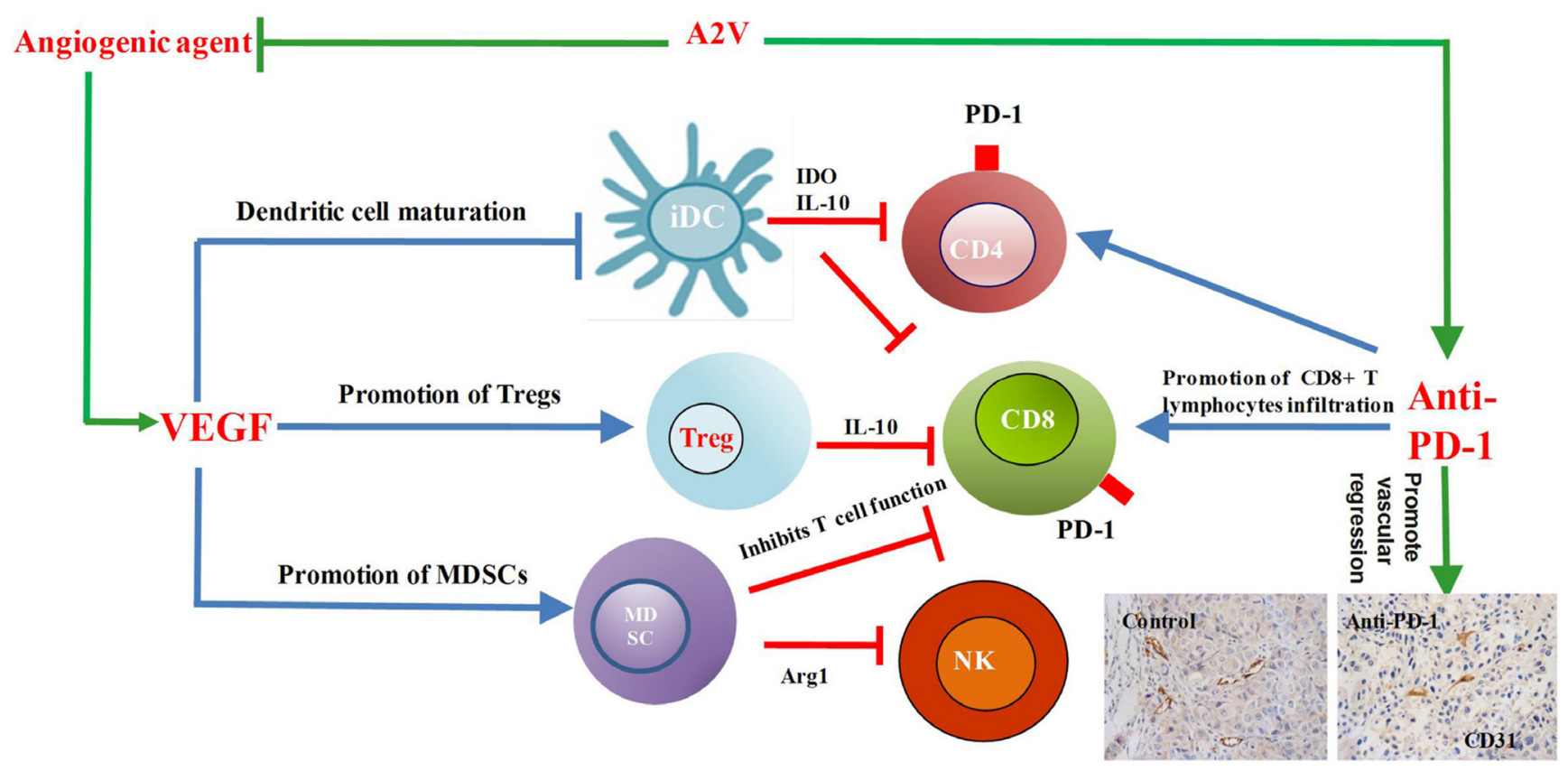

Figure 2: Combined inhibition of tumor angiogenesis and the immune checkpoint PD-1 regulated tumor microenvironment. VEGF, vascular endothelial growth factor; iDC, immature dendritic cell; Treg, Tregulatory cell; MDSC, myeloid -derived suppressor cell; CD4, cluster of differentiation 4; CD8, cluster of differentiation 8; NK, natural killer cell; IDO, indoleamine 2; Arg1, arginase 1; IL-10, interleukin-10; PD-1, programmed cell death protein-1; A2V: bispecific antibody to angiopoietin-2 (ANGPT2) and Vascular endothelial growth factor A (VEGFA). 
NSCLC, there is no study to report to point us in a new direction in the future.

\section{The application of anti-angiogenic agents combined with immunotherapy in in vivo tumor models to regulate the tumor microenvironment}

Until now only two articles reported antiangiogenic agents combined with immunotherapy for antitumor development in the NSCLC models. Endostatin is a $20-\mathrm{kDa}$ fragment of type XVIII collagen that reducing the proliferation, invasion and migration of endothelial cells. It has been proved that rh- endostatin could improve patients' PFS in advanced NSCLC with a combination of chemotherapy in clinical trials [66]. One of the studies at first indicated that rh-endostatin combined with the adoptive cytokine-induced killer cells (CIK cells) transferred to nude mice inhibited the growth of the lung carcinoma. The rh-endostatin could improve the tumor microenvironment by normalizing the tumor vasculature and reducing the hypoxic area. Furthermore, treatment with rh-endostatin significantly increased the homing of CIK cells and tumor-infiltration lymphocytes and decreased the accumulation of MDSCs in the tumor tissue in vivo, providing new insight for combining anti-angiogenesis therapy with immunotherapy in the treatment of NSCLC [67]. Furthermore, this team showed that bevacizumab augments CIK cells in the tumor and the combination of CIK cells significantly inhibits the growth of lung cancer in the mice models [68]. It is interesting to us that no reports have validated the role of anti-angiogenic combined with PD-1 and CTLA-4 inhibitors in the NSCLC models. One of the study showed sunitinib decreased PD-1 expression and increased the infiltration of CD- $4^{+} \mathrm{T}$ cells into the colorectal tumor. Combination of anti-PD-1 antibodies with VEGF-A inhibitors induced a strong antitumor role in colorectal tumor development [64]. Simultaneous blockade of VEGFR2 and PD-1 induced the anti-colon adenocarcinoma effect in vivo. Especially anti-VEGFR2, which inhibits tumor neovascularization and PD-1 blockade, enhanced the local immunity, including IFN- $\gamma$ and TNF- $\alpha$ expression [69].The bispecific antibody (A2V), which blocks angiopoietin-2(ANGPT2) and VEGFA, provides anti-tumor benefits in metastatic breast cancer, pancreatic neuroendocrine tumors and melanoma, including the promotion of vascular regression, normalizing the remaining blood vessels and facilitating the perivascular accumulation of activated CD8+ cytotoxic T lymphocyte (CTL) infiltration. The novelty of this study is that it first identified $\mathrm{A} 2 \mathrm{~V}$ as an anti-tumor strategy that may unleash or increase the efficacy of anti-PD-1 for cancer immunotherapy [70] (Figure 2). Recently, a study found that the combination of anti-VEGFR2 and anti-PD-L1 antibodies induced the generation of endothelial venules(HEVs), which promoted lymphocyte infiltration through the activation of lymphotoxin $\beta$ receptor (LT $\beta$ R) signaling in breast cancer and pancreatic neuroendocrine cancers. Furthermore, anti-angiogenic therapy can improve antiPD-L1 function that facilitates enhanced cytotoxic T cell (CTL) activity and tumor cell destruction [71]. A study investigated the effect of the combination of axitinib, a TKI against VEGFR-1, -2 and -3 , with the therapeutic inhibition of CTLA-4 in subcutaneous and intracranial mouse melanoma models. The combination of axitinib with CTLA-4 inhibitor reduced tumor growth, increased survival and increased the number of CD4+ and CD8+ T cells, intratumoral DCs and suppressive MDSCs in both the intracranial and subcutaneous models [72].

\section{CONCLUSIONS}

Taken together, brain metastases with advanced nonsquamous NSCLC in patients who are more than 70 years old will acquire beneficial and improved PFS and OS with first-line for bevacizumab combined with chemotherapy $[7,13,14]$. However, one of the studies showed that the patients with NSCLC brain metastases seem likely to have extended PFS and OS compared to the non-brain metastases [10]. In addition, treatment of NSCLC brain metastases with bevacizumab in the first line requires further investigation. Second-line advanced non-squamous NSCLC patients are also suitable for accepting antiangiogenesis therapy [41-49]. Anti-angiogenic agents combined with chemotherapy in the first-line or the second line or combine with EGFR-TKI target therapy in advanced NSCLC have shown significant improvements in the ORR, PFS or OS. Meanwhile, these studies did not show sufficient efficacy even though they used the same anti-angiogenic drug. This may be due to the preclinical data suggesting that anti-angiogenic therapies may enhance the stromal and microenvironment, eventually contributing to the different drug resistances and therefore limiting the benefit of these agents.

In recent years, combination immunotherapy with anti-angiogenic agents has become more popular in tumor treatment and have demonstrated potential benefits. However, which patients will acquire the most benefits from this novel therapy is still unknown. It is imperative for us to select biomarkers to aid in choosing these patients. Maybe this approach benefits patient with advanced NSCLC with poor prognosis, including the patients that did not acquire any benefit from checkpoint inhibitor monotherapy, or, for those who were PD-1 negative, failed in the first-line therapy. In addition to the patients' selection, the most appropriate timing, best sequence and the dose of immunotherapy and anti-angiogenic agents is still a crucial problem. One study found that the high dose of anti-angiogenic agents combined with immunotherapy stimulated immune-activation [73].

In conclusion, it is important that more investigation be done to develop and clinically validate the anti- 
angiogenic agents combined with chemotherapy and TKI inhibitor treatments. The new findings indicate that the combination of anti-angiogenic agents and immune checkpoint blockades could have synergistic antitumor functions with less toxicity. However, more challenges remain to be overcome regarding whether combination treatments with chemotherapy, TKI inhibitors or immunotherapy can be realized.

\section{Abbreviations}

FGF: Fibroblast growth factor; FGFR: Fibroblast growth factor receptors; EGF: Epidermal growth factor; EGFR: Epidermal growth factor receptor; VEGF: Vascular endothelial growth factor; VEGFR: Vascular endothelial growth factor receptor; PDGF: Platelet-derived growth factor; PDGFR: Platelet-derived growth factor receptor.

VEGF: Vascular endothelial growth factor; iDC: Immature dendritic cell; Treg: T-regulatory cell; MDSC: Myeloid-derived suppressor cell; CD4:Cluster of differentiation 4; CD8:Cluster of differentiation 8; NK: Natural killer cell; IDO: Indoleamine 2; Arg1: Arginase 1; IL10: Interleukin-10; PD-1:Programmed cell death protein-1; A2V: Bispecific antibody to angiopoietin-2 (ANGPT2) and Vascular endothelial growth factor A (VEGFA).

\section{Author contributions}

J.J.Q. and Y.N. performed wrote the manuscript; J.J.Q. edited the reference; H.Y.Y.and C.H.Z and X.C.design the data; Y.C.Z. modified the manuscript.

\section{CONFLICTS OF INTEREST}

The author declares no conflicts of interest.

\section{REFERENCES}

1. Hanahan D, Weinberg RA. Weinberg, Hallmarks of cancer: the next generation. Cell. 2011; 144:646-674.

2. Hanahan D, Folkman J. Patterns and emerging mechanisms of the angiogenic switch during tumorigenesis. Cell. 1996; 86:353-364.

3. Ferrara N, Kerbel RS. Angiogenesis as a therapeutic target. Nature. 2005; 438:967-974

4. Sandler A, Gray R, Perry MC, Brahmer J, Schiller JH, Dowlati A, Lilenbaum R, Johnson DH. Paclitaxelcarboplatin alone or with bevacizumab for non-small-cell lung cancer. N Engl J Med. 2006; 355:2542-250.

5. Reck M, von Pawel J, Zatloukal P, Ramlau R, Gorbounova V, Hirsh V, Leighl N, Mezger J, Archer V, Moore N, Manegold C. Phase III trial of cisplatin plus gemcitabine with either placebo or bevacizumab as first-line therapy for nonsquamous non-small-cell lung cancer: AVAil. J Clin Oncol. 2009; 27:1227-34
6. Crinò L, Dansin E, Garrido P, Griesinger F, Laskin J, Pavlakis N, Stroiakovski D, Thatcher N, Tsai CM, Wu YL, Zhou C. Safety and efficacy of first-line bevacizumab-based therapy in advanced non-squamous non-small-cell lung cancer (SAiL, MO19390): a phase 4 study. Lancet Oncol. 2010; 11:733-740.

7. Wozniak AJ, Kosty MP, Jahanzeb M, Brahmer JR, Spigel DR, Leon L, Fish S, Flick ED, Hazard SJ, Lynch TJ Jr. Clinical outcomes in elderly patients with advanced nonsmall cell lung cancer: results from ARIES, a bevacizumab observational cohort study. Clin Oncol (R Coll Radiol). 2015; 27:187-96.

8. Niho S, Kunitoh H, Nokihara H, Horai T, Ichinose Y, Hida T, Yamamoto N, Kawahara M, Shinkai T, Nakagawa K, Matsui K, Negoro S, Yokoyama A, et al. Randomized phase II study of first-line carboplatin-paclitaxel with or without bevacizumab in Japanese patients with advanced nonsquamous non-small-cell lung cancer. Lung Cancer. 2012; 76:362-367.

9. Zhou C, Wu YL, Chen G, Liu X, Zhu Y, Lu S, Feng J, He J, Han B, Wang J, Jiang G, Hu C, Zhang H, et al. BEYOND: A Randomized, Double-Blind, Placebo-Controlled, Multicenter, Phase III Study of First-Line Carboplatin/ Paclitaxel Plus Bevacizumab or Placebo in Chinese Patients With Advanced or Recurrent Nonsquamous Non-Small-Cell Lung Cancer. J Clin Oncol. 2015; 33:2197-2204.

10. Stefanou D, Stamatopoulou S, Sakellaropoulou A, Akakios G, Gkiaouraki M, Gkeka D, Prevezanou M, Ardavanis A. Bevacizumab, pemetrexed and carboplatin in first-line treatment of non-small cell lung cancer patients: Focus on patients with brain metastases. Oncol Lett. 2016; 12:4635-4642.

11. Twelves C, Chmielowska E, Havel L, Popat S, SwiebodaSadlej A, Sawrycki P, Bycott P, Ingrosso A, Kim S, Williams JA, Chen C, Olszanski AJ, de Besi P, et al. Randomised phase II study of axitinib or bevacizumab combined with paclitaxel/ carboplatin as first-line therapy for patients with advanced non-small-cell lung cancer. Ann Oncol. 2014; 25:132-138.

12. Besse B, Le Moulec S, Mazières J, Senellart H, Barlesi F, Chouaid C, Dansin E, Bérard H, Falchero L, Gervais R, Robinet G, Ruppert AM, Schott R, et al. Bevacizumab in Patients with Nonsquamous Non-Small Cell Lung Cancer and Asymptomatic, Untreated Brain Metastases (BRAIN): A Nonrandomized, Phase II Study. Clin Cancer Res. 2015; 21:1896-1903.

13. Kozuki T, Nogami N, Kitajima H, Iwasawa S, Sakaida E, Takiguchi Y, Ikeda S, Yoshida M, Kato T, Miyamoto S, Sakamaki K, Shinkai T, Watanabe K. Feasibility study of firstline chemotherapy using Pemetrexed and Bevacizumab for advanced or recurrent nonsquamous non-small cell lung cancer in elderly patients: TORG1015. BMC Cancer. 2016; 16:306.

14. Miura S, Maemondo M, Iwashima A, Harada T, Sugawara $\mathrm{S}$, Kobayashi K, Inoue A, Nakagawa T, Takiguchi Y, Watanabe H, Ishida T, Terada M, Kagamu H, et al. A phase II study of carboplatin plus weekly paclitaxel with bevacizumab for elderly patients with non-squamous non- 
small-cell lung cancer (NEJ016). Invest New Drugs; 2017; $35: 227-234$.

15. Kim TJ, Ravoori M, Landen CN, Kamat AA, Han LY, Lu C, Lin YG, Merritt WM, Jennings N, Spannuth WA, Langley R, Gershenson DM, Coleman RL, et al. Antitumor and antivascular effects of AVE8062 in ovarian carcinoma. Cancer Res. 2007; 67:9337-9345.

16. von Pawel J, Gorbounova V, Reck M, Kowalski DM, Allard A, Chadjaa M, Rey A, Bennouna J, Grossi F. DISRUPT: a randomised phase 2 trial of ombrabulin (AVE8062) plus a taxane-platinum regimen as first-line therapy for metastatic non-small cell lung cancer. Lung Cancer. 2014; 85:224-229.

17. Hu-Lowe DD, Zou HY, Grazzini ML, Hallin ME, Wickman GR, Amundson K, Chen JH, Rewolinski DA, Yamazaki $\mathrm{S}, \mathrm{Wu}$ EY, McTigue MA, Murray BW, Kania RS, et al. Nonclinical antiangiogenesis and antitumor activities of axitinib (AG-013736), an oral, potent, and selective inhibitor of vascular endothelial growth factor receptor tyrosine kinases 1, 2, 3. Clin Cancer Res. 2008; 14:7272-7283.

18. Rugo HS, Herbst RS, Liu G, Park JW, Kies MS, Steinfeldt HM, Pithavala YK, Reich SD, Freddo JL, Wilding G. Phase I trial of the oral antiangiogenesis agent AG-013736 in patients with advanced solid tumors: pharmacokinetic and clinical results. J Clin Oncol. 2005; 23:5474-5483.

19. Schiller JH, Larson T, Ou SH, Limentani S, Sandler A, Vokes E, Kim S, Liau K, Bycott P, Olszanski AJ, von Pawel J. Efficacy and safety of axitinib in patients with advanced non-small-cell lung cancer: results from a phase II study. J Clin Oncol. 2009; 27:3836-3841.

20. Belani CP, Yamamoto N, Bondarenko IM, Poltoratskiy A, Novello S, Tang J, Bycott P, Niethammer AG, Ingrosso A, Kim S, Scagliotti GV. Randomized phase II study of pemetrexed/ cisplatin with or without axitinib for non-squamous non-smallcell lung cancer. BMC Cancer. 2014; 14:290.

21. Doebele RC, Spigel D, Tehfe M, Thomas S, Reck M, Verma S, Eakle J, Bustin F, Goldschmidt J Jr, Cao D, Alexandris E, Yurasov S, Camidge DR, et al. Phase 2, randomized, openlabel study of ramucirumab in combination with first-line pemetrexed and platinum chemotherapy in patients with nonsquamous, advanced/metastatic non-small cell lung cancer. Cancer. 2015; 121:883-892.

22. Camidge DR, Berge EM, Doebele RC, Ballas MS, Jahan T, Haigentz M Jr, Hoffman D, Spicer J, West H, Lee P, Yang L, Joshi A, Gao L, et al. A phase II, open-label study of ramucirumab in combination with paclitaxel and carboplatin as first-line therapy in patients with stage IIIB/IV non-small-cell lung cancer. J Thorac Oncol. 2014; 9:1532-1539.

23. DeRose P, Thorpe PE, Gerber DE. Development of bavituximab, a vascular targeting agent with immunemodulating properties, for lung cancer treatment. Immunotherapy. 2011; 3:933-944.

24. Digumarti R, Bapsy PP, Suresh AV, Bhattacharyya GS, Dasappa L, Shan JS, Gerber DE. Bavituximab plus paclitaxel and carboplatin for the treatment of advanced non-small-cell lung cancer. Lung Cancer. 2014; 86:231-236.

25. Digumarti R, Bapsy PP, Suresh AV, Bhattacharyya GS, Dasappa L, Shan JS, Gerber DE. A phase 1 study of linifanib in combination with carboplatin/paclitaxel as first-line treatment of Japanese patients with advanced or metastatic non-small cell lung cancer (NSCLC). Cancer Chemother Pharmacol. 2014; 74:37-43.

26. Ramalingam SS, Shtivelband $\mathrm{M}$, Soo RA, Barrios $\mathrm{CH}$, Makhson A, Segalla JG, Pittman KB, Kolman P, Pereira JR, Srkalovic G, Belani CP, Axelrod R, Owonikoko TK, et al. Randomized phase II study of carboplatin and paclitaxel with either linifanib or placebo for advanced nonsquamous non-small-cell lung cancer. J Clin Oncol. 2015; 33:433-441.

27. Dy GK, Mandrekar SJ, Nelson GD, Meyers JP, Adjei AA, Ross HJ, Ansari RH, Lyss AP, Stella PJ, Schild SE, Molina JR, Adjei AA. A randomized phase II study of gemcitabine and carboplatin with or without cediranib as first-line therapy in advanced non-small-cell lung cancer: North Central Cancer Treatment Group Study N0528. J Thorac Oncol. 2013; 8:79-88.

28. Laurie SA, Solomon BJ, Seymour L, Ellis PM, Goss GD, Shepherd FA, Boyer MJ, Arnold AM, Clingan P, Laberge F, Fenton D, Hirsh V, Zukin M, et al. Randomised, doubleblind trial of carboplatin and paclitaxel with daily oral cediranib or placebo in patients with advanced non-small cell lung cancer: NCIC Clinical Trials Group study BR29. Eur J Cancer. 2014; 50:706-712.

29. Goss GD, Arnold A, Shepherd FA, Dediu M, Ciuleanu TE, Fenton D, Zukin M, Walde D, Laberge F, Vincent MD, Ellis PM, Laurie SA, Ding K, et al. Randomized, double-blind trial of carboplatin and paclitaxel with either daily oral cediranib or placebo in advanced non-small-cell lung cancer: NCIC clinical trials group BR24 study. J Clin Oncol. 2010; 28:49-55.

30. O'Brien ME, Gaafar R, Hasan B, Menis J, Cufer T, Popat S, Woll PJ, Surmont V, Georgoulias V, Montes A, Blackhall F, Hennig I, Schmid-Bindert G, et al. Maintenance pazopanib versus placebo in Non-Small Cell Lung Cancer patients non-progressive after first line chemotherapy: A double blind randomised phase III study of the lung cancer group, EORTC 08092 (EudraCT: 2010-018566-23, NCT01208064). Eur J Cancer. 2015; 51:1511-1528.

31. Scagliotti GV, Felip E, Besse B, von Pawel J, Mellemgaard A, Reck M, Bosquee L, Chouaid C, Lianes-Barragán P, Paul EM, Ruiz-Soto R, Sigal E, Ottesen LH, et al. An openlabel, multicenter, randomized, phase II study of pazopanib in combination with pemetrexed in first-line treatment of patients with advanced-stage non-small-cell lung cancer. J Thorac Oncol. 2013; 8:1529-1537.

32. Blumenschein GR Jr, Reckamp K, Stephenson GJ, O'Rourke T, Gladish G, McGreivy J, Sun YN, Ye Y, Parson M, Sandler A. Phase 1b study of motesanib, an oral angiogenesis inhibitor, in combination with carboplatin/paclitaxel and/or panitumumab for the treatment of advanced non-small cell lung cancer. Clin Cancer Res. 2010; 16:279-290. 
33. Blumenschein GR Jr, Kabbinavar F, Menon H, Mok TS, Stephenson J, Beck JT, Lakshmaiah K, Reckamp K, Hei YJ, Kracht K, Sun YN, Sikorski R, Schwartzberg L. A phase II, multicenter, open-label randomized study of motesanib or bevacizumab in combination with paclitaxel and carboplatin for advanced nonsquamous non-small-cell lung cancer. Ann Oncol. 2011; 22:2057-67.

34. Scagliotti GV, Vynnychenko I, Park K, Ichinose Y, Kubota K, Blackhall F, Pirker R, Galiulin R, Ciuleanu TE, Sydorenko O, Dediu M, Papai-Szekely Z, Banaclocha NM. International, randomized, placebo-controlled, double-blind phase III study of motesanib plus carboplatin/paclitaxel in patients with advanced nonsquamous non-small-cell lung cancer: MONET1. J Clin Oncol. 2012; 30:2829-2836.

35. Novello S, Scagliotti GV, Sydorenko O, Vynnychenko I, Volovat C, Schneider CP, Blackhall F, McCoy S, Hei YJ, Spigel DR. Motesanib plus carboplatin/paclitaxel in patients with advanced squamous non-small-cell lung cancer: results from the randomized controlled MONET1 study. J Thorac Oncol. 2014; 9:1154-1161.

36. Heymach JV, Paz-Ares L, De Braud F, Sebastian M, Stewart DJ, Eberhardt WE, Ranade AA, Cohen G, Trigo JM, Sandler AB, Bonomi PD, Herbst RS, Krebs AD, et al. Randomized phase II study of vandetanib alone or with paclitaxel and carboplatin as first-line treatment for advanced non-small-cell lung cancer. J Clin Oncol. 2008; 26:5407-5415.

37. Blackhall FH, O'Brien M, Schmid P, Nicolson M, Taylor P, Milenkova T, Kennedy SJ, Thatcher N. A phase I study of Vandetanib in combination with vinorelbine/cisplatin or gemcitabine/cisplatin as first-line treatment for advanced nonsmall cell lung cancer. J Thorac Oncol. 2010; 5:1285-1288.

38. Gridelli C, Novello S, Zilembo N, Luciani A, Favaretto AG, De Marinis F, Genestreti G, Crinò L, Grossi F, Caffo O, Ferraù F, Cruciani G, Brandes AA, et al. Phase II randomized study of vandetanib plus gemcitabine or gemcitabine plus placebo as first-line treatment of advanced non-small-cell lung cancer in elderly patients. J Thorac Oncol. 2014; 9:733-737.

39. Doebele RC, Conkling P, Traynor AM, Otterson GA, Zhao Y, Wind S, Stopfer P, Kaiser R, Camidge DR. A phase I, openlabel dose-escalation study of continuous treatment with BIBF 1120 in combination with paclitaxel and carboplatin as first-line treatment in patients with advanced non-smallcell lung cancer. Ann Oncol. 2012; 23:2094-2102.

40. Reck M, Kaiser R, Eschbach C, Stefanic M, Love J, Gatzemeier U, Stopfer P, von Pawel J. A phase II doubleblind study to investigate efficacy and safety of two doses of the triple angiokinase inhibitor BIBF 1120 in patients with relapsed advanced non-small-cell lung cancer. Ann Oncol. 2011; 22:1374-1381.

41. Quan R, Huang J, Chen N, Fang W, Hu Z, Zhan J, Zhou T, Zhang L, Zhang H. A retrospective analysis of efficacy and safety of adding bevacizumab to chemotherapy as first- and second-line therapy in advanced non-small-cell lung cancer (NSCLC). Tumour Biol. 2016; 37:11479-11484.
42. Hattori Y, Satouchi M, Shimada T, Urata Y, Yoneda T, Mori M, Nishimura T, Sunadome H, Kumagai T, Imamura F, Fujita S, Kaji R, Hata A, et al. A phase 2 study of bevacizumab in combination with carboplatin and paclitaxel in patients with non-squamous non-small-cell lung cancer harboring mutations of epidermal growth factor receptor (EGFR) after failing first-line EGFR-tyrosine kinase inhibitors (HANSHIN Oncology Group 0109). Lung Cancer. 2015; 87:136-140.

43. Reck M, Kaiser R, Mellemgaard A, Douillard JY, Orlov S, Krzakowski M, von Pawel J, Gottfried M, Bondarenko I, Liao M, Gann CN, Barrueco J, Gaschler-Markefski B. Docetaxel plus nintedanib versus docetaxel plus placebo in patients with previously treated non-small-cell lung cancer (LUME-Lung 1): a phase 3, double-blind, randomised controlled trial. Lancet Oncol. 2014; 15:143-155.

44. Heist RS, Wang X, Hodgson L, Otterson GA, Stinchcombe TE, Gandhi L, Villalona-Calero MA, Watson P, Vokes EE, Socinski MA. CALGB 30704 (Alliance): A randomized phase II study to assess the efficacy of pemetrexed or sunitinib or pemetrexed plus sunitinib in the second-line treatment of advanced non-small-cell lung cancer. J Thorac Oncol. 2014; 9:214-221.

45. Hess-Stumpp H, Haberey M, Thierauch KH. PTK 787/ZK 222584, a tyrosine kinase inhibitor of all known VEGF receptors, represses tumor growth with high efficacy. Chembiochem. 2005; 6:550-557.

46. Gauler TC, Besse B, Mauguen A, Meric JB, Gounant V, Fischer B, Overbeck TR, Krissel H, Laurent D, Tiainen M, Commo F, Soria JC, Eberhardt WE. Phase II trial of PTK787/ZK 222584 (vatalanib) administered orally once-daily or in two divided daily doses as second-line monotherapy in relapsed or progressing patients with stage IIIB/IV non-small-cell lung cancer (NSCLC). Ann Oncol. 2012; 23:678-687.

47. Yoh K, Hosomi Y, Kasahara K, Yamada K, Takahashi T, Yamamoto N, Nishio M, Ohe Y, Koue T, Nakamura T, Enatsu S, Lee P, Ferry D, et al. A randomized, double-blind, phase II study of ramucirumab plus docetaxel vs placebo plus docetaxel in Japanese patients with stage IV non-small cell lung cancer after disease progression on platinum-based therapy. Lung Cancer. 2016; 99:186-193.

48. Garon EB, Ciuleanu TE, Arrieta O, Prabhash K, Syrigos KN, Goksel T, Park K, Gorbunova V, Kowalyszyn RD, Pikiel J, Czyzewicz G, Orlov SV, Lewanski CR, et al. Ramucirumab plus docetaxel versus placebo plus docetaxel for second-line treatment of stage IV non-small-cell lung cancer after disease progression on platinum-based therapy (REVEL): a multicentre, double-blind, randomised phase 3 trial. Lancet. 2014; 384:665-73.

49. Shtivelband M, Spigel DR, Gerber DE, Jain MM, Ponomarova OV, Giorgadze D, Shan J, Menander KB, Belani CP. J Clin Oncol (Meeting Abstracts). 2013; 31(suppl:8095).

50. Costa C, Molina MA, Drozdowskyj A, Giménez-Capitán A, Bertran-Alamillo J, Karachaliou N, Gervais R, Massuti 
B, Wei J, Moran T, Majem M, Felip E, Carcereny E. The impact of EGFR T790M mutations and BIM mRNA expression on outcome in patients with EGFR-mutant NSCLC treated with erlotinib or chemotherapy in the randomized phase III EURTAC trial. Clin Cancer Res. 2014; 20:2001-2010.

51. Ciuleanu T, Tsai CM, Tsao CJ, Milanowski J, Amoroso D, Heo DS, Groen HJ, Szczesna A, Chung CY, Chao TY, Middleton G, Zeaiter A, Klingelschmitt G, et al. A phase II study of erlotinib in combination with bevacizumab versus chemotherapy plus bevacizumab in the first-line treatment of advanced non-squamous non-small cell lung cancer. Lung Cancer. 2013; 82:276-281.

52. Thomas M, Fischer J, Andreas S, Kortsik C, Grah C, Serke M, von Eiff M, Witt C, Kollmeier J, Müller E, Schenk M, Schröder M, Villalobos M, et al. Erlotinib and bevacizumab versus cisplatin, gemcitabine and bevacizumab in unselected nonsquamous nonsmall cell lung cancer. Eur Respir J. 2015; 46:219-229.

53. Ichihara E, Hotta K, Nogami N, Kuyama S, Kishino D, Fujii M, Kozuki T, Tabata M, Harada D, Chikamori K, Aoe K, Ueoka H, Hosokawa S, et al. Phase II trial of gefitinib in combination with bevacizumab as first-line therapy for advanced non-small cell lung cancer with activating EGFR gene mutations: the Okayama Lung Cancer Study Group Trial 1001. J Thorac Oncol. 2015; 10:486-491.

54. Rosell R, Dafni U, Felip E, Curioni-Fontecedro A, Gautschi O, Peters S, Massutí B, Palmero R, Aix SP, Carcereny E, Früh M, Pless M, Popat S, et al. Erlotinib and bevacizumab in patients with advanced non-small-cell lung cancer and activating EGFR mutations (BELIEF): an international, multicentre, single-arm, phase 2 trial. Lancet Respir Med. 2017; 5:435-444.

55. Groen HJ, Socinski MA, Grossi F, Juhasz E, Gridelli C, Baas P, Butts CA, Chmielowska E, Usari T, Selaru P, Harmon C, Williams JA, Gao F, et al. A randomized, double-blind, phase II study of erlotinib with or without sunitinib for the second-line treatment of metastatic non-small-cell lung cancer (NSCLC). Ann Oncol. 2013; 24:2382-2389.

56. Liu YR, Zhu W, Zhang JL, Huang JQ, Zhao YZ, Zhang W, Han BH, Yao YH, Jiang LY, Li SQ. The evaluation of efficacy and safety of sunitinib on EGFR-TKI pretreated advanced non-small cell lung cancer patients in China. Clin Respir J. 2014; 8:206-212.

57. Paz-Ares L, Hirsh V, Zhang L, de Marinis F, Yang JC, Wakelee HA, Seto T, Wu YL, Novello S, Juhász E, Arén O, Sun Y, Schmelter T, et al. Monotherapy Administration of Sorafenib in Patients With Non-Small Cell Lung Cancer (MISSION) Trial: A Phase III, Multicenter, PlaceboControlled Trial of Sorafenib in Patients with Relapsed or Refractory Predominantly Nonsquamous Non-Small-Cell Lung Cancer after 2 or 3 Previous Treatment Regimens. J Thorac Oncol. 2015; 10:1745-1753.

58. Zhou Q, Zhou CC, Chen GY, Cheng Y, Huang C, Zhang
L, Xu CR, Li AW, Yan HH, Su J, Zhang XC, Yang JJ, Wu YL. A multicenter phase II study of sorafenib monotherapy in clinically selected patients with advanced lung adenocarcinoma after failure of EGFR-TKI therapy (Chinese Thoracic Oncology Group, CTONG 0805). Lung Cancer. 2014; 83:369-373.

59. Spigel DR, Burris HA, Greco FA, Shipley DL, Friedman EK, Waterhouse DM, Whorf RC, Mitchell RB, Daniel DB, Zangmeister J, Bass JD, Hainsworth JD. Randomized, double-blind, placebo-controlled, phase II trial of sorafenib and erlotinib or erlotinib alone in previously treated advanced non-small-cell lung cancer. J Clin Oncol. 2011; 29:2582-2589.

60. Gridelli C, Morgillo F, Favaretto A, de Marinis F, Chella A, Cerea G, Mattioli R, Tortora G, Rossi A, Fasano M, Pasello G, Ricciardi S, Maione P, et al. Sorafenib in combination with erlotinib or with gemcitabine in elderly patients with advanced non-small-cell lung cancer: a randomized phase II study. Ann Oncol. 2011; 22:1528-1534.

61. Lim SM, Cho BC, Kim SW, Kang SY, Heo DS, Kim HT, Lee DH, Kim DW, Jung M, Choi JH, Shim HS, Choi JR, Kim JH. A multicenter phase II study of sorafenib in combination with erlotinib in patients with advanced non-small cell lung cancer (KCSG-0806). Lung Cancer. 2016; 93:1-8.

62. Manegold C, Dingemans AC, Gray JE, Nakagawa K, Nicolson M, Peters S, Reck M, Wu YL, Brustugun OT, Crinò L, Felip E, Fennell D, Garrido P, et al. The Potential of Combined Immunotherapy and Antiangiogenesis for the Synergistic Treatment of Advanced NSCLC. J Thorac Oncol. 2017; 12:194-207.

63. Church SE, Galon J. Tumor Microenvironment and Immunotherapy: The Whole Picture Is Better Than a Glimpse. Immunity. 2015; 43:631-633.

64. Voron T, Colussi O, Marcheteau E, Pernot S, Nizard M, Pointet AL, Latreche S, Bergaya S, Benhamouda N, Tanchot C, Stockmann C, Combe P, Berger A, et al. VEGF-A modulates expression ofinhibitory checkpoints on CD8+ T cells in tumors. J Exp Med. 2015; 212:139-148.

65. Rizvi NA, Antonia SJ, Shepherd LQ, Chow J, Goldman Y, Shen AC, Chen S. Nivolumab (Anti-PD-1; BMS936558, ONO- 4538) Maintenance as Monotherapy or in Combination With Bevacizumab (BEV) for Non-Small Cell Lung Cancer (NSCLC) Previously Treated With Chemotherapy. Radiation Oncol. 2014; 90:S32.

66. Huang G, Chen L. Recombinant human endostatin improves anti- tumor efficacy of paclitaxel by normalizing tumor vasculature in Lewis lung carcinoma. J Cancer Res Clin Oncol. 2010; 136:1201-1211.

67. Shi S, Wang R, Chen Y, Song H, Chen L, Huang G. Combining antiangiogenic therapy with adoptive cell immunotherapy exerts better antitumor effects in non-small cell lung cancer models. PLoS One. 2013; 8:e65757.

68. Tao L, Huang G, Shi S, Chen L. Bevacizumab improves the antitumor efficacy of adoptive cytokine-induced killer cells therapy in non-small cell lung cancer models. Med Oncol. 
2014; 31:777.

69. Yasuda S, Sho M, Yamato I, Yoshiji H, Wakatsuki K, Nishiwada S, Yagita H, Nakajima Y. Simultaneous blockade of programmed death 1 and vascular endothelial growth factor receptor 2 (VEGFR2) induces synergistic anti- tumour effect in vivo. Clin Exp Immunol. 2013; 172:500-506.

70. Schmittnaegel M, Rigamonti N, Kadioglu E, Cassará A, Wyser Rmili C, Kiialainen A, Kienast Y, Mueller HJ, Ooi CH, Laoui D, De Palma M. Dual angiopoietin-2 and VEGFA inhibition elicits antitumor immunity that is enhanced by PD-1 checkpoint blockade. Sci Transl Med. 2017; 9:eaak9670.

71. Allen E, Jabouille A, Rivera LB, Lodewijckx I, Missiaen R, Steri V, Feyen K, Tawney J, Hanahan D, Michael IP, Bergers G. Combined antiangiogenic and anti-PD-L1 therapy stimulates tumor immunity through HEV formation.
Sci Transl Med. 2017; 9: eaak9679.

72. Four SD, Maenhout SK, Niclou SP, Thielemans K, Neyns B, Aerts JL. Combined VEGFR and CTLA-4 blockade increases the antigen-presenting function of intratumoral DCs and reduces the suppressive capacity of intratumoral MDSCs. Am J Cancer Res. 2016; 6:2514-2531

73. Huang Y, Yuan J, Righi E, Kamoun WS, Ancukiewicz M, Nezivar J, Santosuosso M, Martin JD, Martin MR, Vianello F, Leblanc P, Munn LL, Huang P, et al. Vascular normalizing doses of antiangiogenic treatment reprogram the immunosuppressive tumor microenvironment and enhance immunotherapy. Proc Natl Acad Sci USA. 2012; 109:17561-17566. 